\title{
Sugary Logistics Gone Wrong: Membrane Trafficking and Congenital Disorders of Glycosylation
}

\author{
Peter T. A. Linders ${ }^{1}{ }^{\complement}$, Ella Peters ${ }^{1}$, Martin ter Beest ${ }^{1}$, Dirk J. Lefeber ${ }^{2,3, *}$ and \\ Geert van den Bogaart 1,4,*(D) \\ 1 Tumor Immunology Lab, Radboud University Medical Center, Radboud Institute for Molecular Life Sciences, \\ Geert Grooteplein 28, 6525 GA Nijmegen, The Netherlands; peter.linders@radboudumc.nl (P.T.A.L.); \\ ella.peters@kpnmail.nl (E.P.); martin.terbeest@radboudumc.nl (M.t.B.) \\ 2 Department of Neurology, Donders Institute for Brain, Cognition and Behaviour, Radboud University \\ Medical Center, Geert Grooteplein 10, 6525 GA Nijmegen, The Netherlands \\ 3 Department of Laboratory Medicine, Translational Metabolic Laboratory, Radboud University Medical \\ Center, Geert Grooteplein 10, 6525 GA Nijmegen, The Netherlands \\ 4 Department of Molecular Immunology, Groningen Biomolecular Sciences and Biotechnology Institute, \\ University of Groningen, Nijenborgh 7, 9747 AG Groningen, The Netherlands \\ * Correspondence: dirk.lefeber@radboudumc.nl (D.J.L.); g.van.den.bogaart@rug.nl (G.v.d.B.); \\ Tel.: +31-24-36-14567 (D.J.L.); +31-50-36-35230 (G.v.d.B.)
}

Received: 16 June 2020; Accepted: 26 June 2020; Published: 30 June 2020

\begin{abstract}
Glycosylation is an important post-translational modification for both intracellular and secreted proteins. For glycosylation to occur, cargo must be transported after synthesis through the different compartments of the Golgi apparatus where distinct monosaccharides are sequentially bound and trimmed, resulting in increasingly complex branched glycan structures. Of utmost importance for this process is the intraorganellar environment of the Golgi. Each Golgi compartment has a distinct $\mathrm{pH}$, which is maintained by the vacuolar $\mathrm{H}^{+}$-ATPase (V-ATPase). Moreover, tethering factors such as Golgins and the conserved oligomeric Golgi (COG) complex, in concert with coatomer (COPI) and soluble N-ethylmaleimide-sensitive factor attachment protein receptor (SNARE)-mediated membrane fusion, efficiently deliver glycosylation enzymes to the right Golgi compartment. Together, these factors maintain intra-Golgi trafficking of proteins involved in glycosylation and thereby enable proper glycosylation. However, pathogenic mutations in these factors can cause defective glycosylation and lead to diseases with a wide variety of symptoms such as liver dysfunction and skin and bone disorders. Collectively, this group of disorders is known as congenital disorders of glycosylation (CDG). Recent technological advances have enabled the robust identification of novel CDGs related to membrane trafficking components. In this review, we highlight differences and similarities between membrane trafficking-related CDGs.
\end{abstract}

Keywords: post-translational modification; glycosylation; membrane trafficking; Golgi apparatus; secretory pathway; congenital disorders of glycosylation

\section{Introduction}

The conjugation of oligosaccharide structures to proteins, glycosylation, is a ubiquitous and fundamental post-translational modification found in all domains of life. Glycosylation is not only important for the structure and function of proteins, but also for their transit and selective targeting through the secretory pathway [1-7]. In mammals, approximately 700 proteins are necessary for generating the full diversity of over 7000 glycan structures [8-12]. The addition of glycan structures in vertebrates is a sequential process and involves both the addition of monosaccharides via glycosyltransferases and the trimming of glycans by glycosidases [13]. Only ten different 
monosaccharides are required to build the full glycan spectrum: fucose (Fuc), galactose (Gal), glucose (Glc), N-acetylgalactosamine (GalNAc), N-acetylglucosamine (GlcNAc), glucuronic acid (GlcA), mannose (Man), sialic acid (SA, also known as neuraminic acid), xylose (Xyl), and recently identified ribitol $[8,10,11,14]$.

In vertebrates, $\mathrm{N}$-glycan synthesis is initiated in the ER as a 14 monosaccharide precursor on the carrier lipid dolichol. During translation, this glycan is transferred by oligosaccharyltransferase (OST) [15-17] from dolichol to the nascent polypeptide at acceptor peptide sequons, generally consisting of an Asn-X-(Ser/Thr) motif [18-21]. Distal glucose moieties of these immature, high glucose and mannose containing, glycan structures are subsequently trimmed before Golgi entry; an important step in the control of misfolded glycoproteins in the ER [5,22,23]. Glycoproteins then exit the ER via, for instance, cargo receptor ERGIC-53 [24-26] and are transported to the Golgi apparatus for further processing. In the Golgi, glycoproteins are trimmed, extended, and branched until they reach their final glycan form. The mammalian Golgi apparatus is a single large perinuclear organelle, organized into discrete compartments or cisternae [27-29]. The Golgi can be subdivided into cis-Golgi, closest to the ER, medial-Golgi, trans-Golgi, and the trans-Golgi network (TGN), furthest away from the nucleus. Furthermore, mammals have a pre-Golgi compartment known as the ER-Golgi intermediate compartment (ERGIC, previously known as the vesicular-tubular cluster (VTC)) [30,31]. Newly synthesized glycoproteins emanating from the ER enter the Golgi apparatus at the cis-Golgi, sequentially pass through medial- and trans-Golgi, and finally, exit the Golgi at the TGN. The compartmentalization of the Golgi allows for distinct environments containing subsets of glycosylation enzymes [32-35], enabling sequential modifications for the formation of completely mature glycoproteins. The organization of Golgi-resident enzymes and the Golgi apparatus itself differs between cell types, contributing to glycoprotein diversity [28,36-39]. Two examples are the distribution of $\alpha$-mannosidases I and II, which primarily localize to the trans-Golgi in intestinal goblet cells, but are distributed over all Golgi cisternae in hepatocytes, the functional consequences of which are currently unknown [39].

Efficient glycosylation fully relies on the correct localization of glycosylation enzymes, as well as on the delivery of other glycosylation machinery, such as nucleotide sugar transporters, and cargo proteins to be glycosylated to the correct Golgi compartment. An important factor involved in the correct trafficking of glycosylation enzymes is the maintenance of $\mathrm{pH}$ within the Golgi apparatus. In eukaryotic cells, the principal proton pump for the regulation of intraorganellar $\mathrm{pH}$ is the vacuolar $\mathrm{H}^{+}$-ATPase (V-ATPase). The membrane $\mathrm{V}_{0}$ domain anchors this complex in the membrane, and the $\mathrm{V}_{1}$ domain is cytosolic [40]. The $\mathrm{V}_{0}$ domain contains six different subunits (a, $\mathrm{d}, \mathrm{e}, \mathrm{c}, \mathrm{c}^{\prime}$, and $\left.\mathrm{c}^{\prime \prime}\right)$. This domain functions as a proton translocator across the membrane, which not only results in a pH gradient, but also in a change in membrane potential, which is neutralized by counter ions such as $\mathrm{K}^{+}$and $\mathrm{Cl}^{-}$. The cytosolic $\mathrm{V}_{1}$ domain contains eight subunits (A-H), and its main function is ATP hydrolysis [40] to provide the energy needed for the $\mathrm{pH}$ gradient. In mammals, the specificity of V-ATPase localization is encoded in the $\mathrm{V}_{0}$ a subunit, as four unique isoforms exist $\left(\mathrm{V}_{0} \mathrm{a} 1-4\right)$. This is in contrast to Saccharomyces cerevisiae, which has only two unique isoforms (Vph1p and Stv1p) [40-44]. The diversity in $\mathrm{V}_{0} \mathrm{a}$ subunits is likely important for specific cell type-dependent functions and differential regulation of the $\mathrm{pH}$ in different organelles. Isoform $\mathrm{V}_{0} \mathrm{a} 1$ is targeted to secretory vesicles and $\mathrm{V}_{0} \mathrm{a} 2$ to the Golgi and endosomes, and $V_{0} a 3$, highly expressed in macrophages and osteoclasts $[45,46]$, is enriched in late endosomes and lysosomes, while $\mathrm{V}_{0}$ a4 is mainly expressed in the kidney, inner ear, and ocular ciliary body [47-50]. The V-ATPase ensures a constant $\mathrm{pH}$ in the various Golgi compartments, which ranges from 6.7 for the cis-Golgi to 6.0 for the trans-Golgi [51]. Given the $\mathrm{pH}$ optima of glycosylation enzymes, this $\mathrm{pH}$ gradient could restrict the activity of glycosylation enzymes to their target Golgi compartment [52]. However, this might not be the complete explanation considering the broad distribution of $\mathrm{pH}$ optima and the small differences in absolute $\mathrm{pH}$ between the cisternae. Instead, or additionally, the $\mathrm{pH}$-sensitive binding and release to cargo adapters might ensure correct enzyme localization to the target Golgi compartment [53-55]. 
Several models for the trafficking routes in the Golgi exist, but the most favorable model of membrane traffic within the Golgi is the cisternal maturation model (Figure 1) [56]. Cisternal maturation is the gradual conversion of a Golgi compartment by the delivery of proteins and lipids from more mature Golgi compartments concomitant with the removal of Golgi proteins and lipids from previous Golgi compartments by coatomer (coat protein complex I; COPI)-mediated retrograde membrane trafficking $[27,56]$. Before membrane fusion of these COPI vesicles, a set of molecular instruments orchestrates correct vesicle targeting to and within the Golgi. An important group of such trafficking factors is the Golgin family, which consist of large coiled-coil proteins that associate with the Golgi membrane. Golgins form a tentacular web in the cytosol that efficiently and selectively tethers cargo vesicles [57-59]. Concurrently, Golgins can act as scaffolding proteins for small Rab or Arf GTPases [60-62]. At the Golgi, Rab6 and Rab30 can recruit effectors, such as the cytoskeletal motor protein myosin II, for vesicle trafficking [63-67]. Completing the ensemble is the conserved oligomeric Golgi (COG) tethering complex, a hetero-octameric protein complex bridging the Golgi membrane and COPI vesicles [68,69]. Finally, when the Golgi membrane and the uncoated COPI vesicle are in close enough proximity, membrane fusion occurs. Membrane fusion is performed by soluble N-ethylmaleimide-sensitive factor attachment protein receptor (SNARE) proteins.

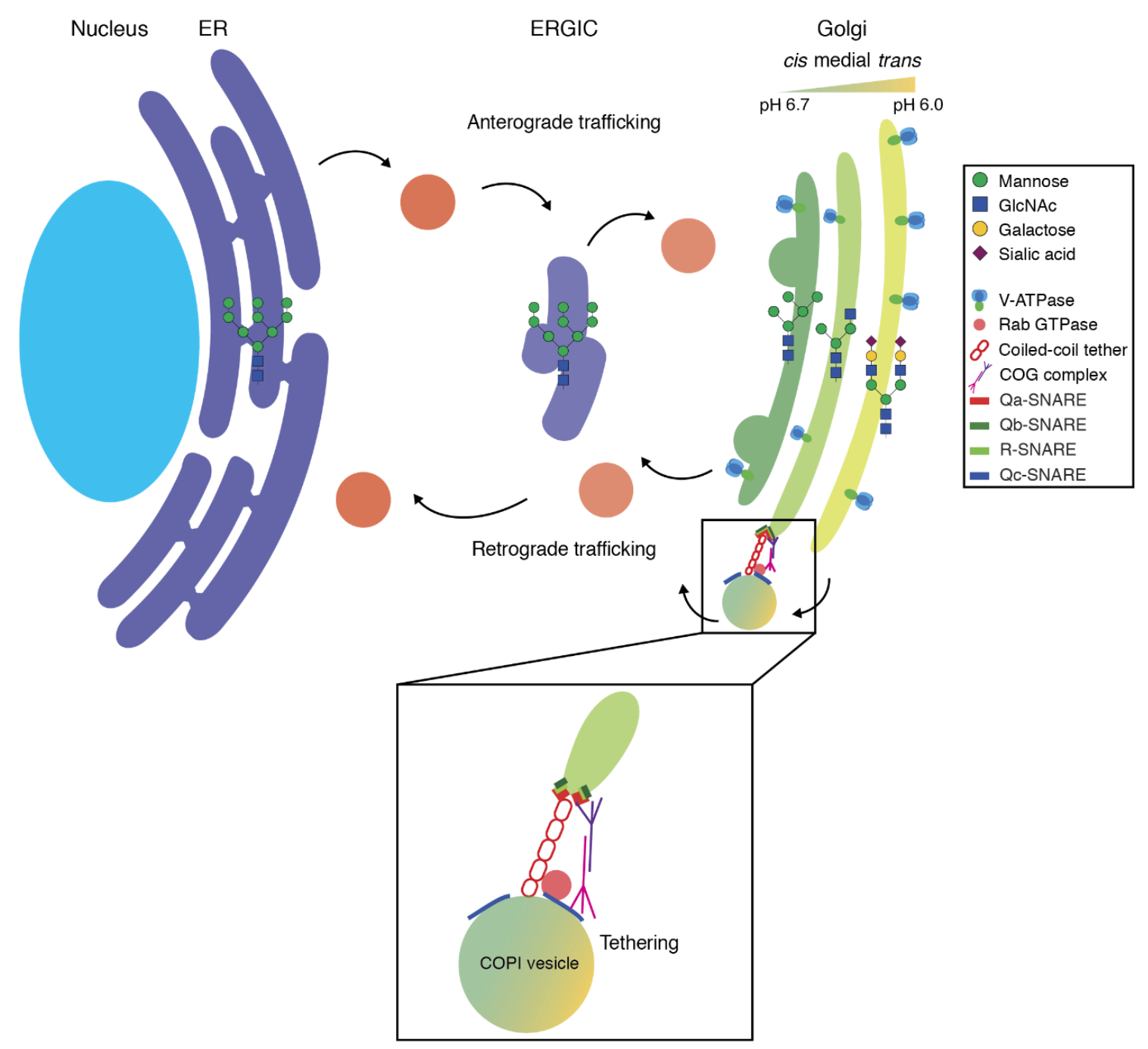

Figure 1. Schematic overview of the early secretory pathway in mammalian cells. Abbreviations: ER, endoplasmic reticulum; ERGIC, endoplasmic reticulum-Golgi intermediate compartment; COG complex, conserved oligomeric Golgi complex; COPI, coat protein complex I. 
As glycosylation is such an extensive process with a multitude of different factors that operate together for sequential remodeling of glycan moieties, only slight disturbances can have major implications on glycosylation. As such, over 100 monogenic diseases have been identified characterized by dysfunctional glycosylation, which form a group collectively known as congenital disorders of glycosylation (CDG) [53,70,71]. A large subset of these includes genetic variants in the prior mentioned trafficking proteins, but also in subunits of the vacuolar $\mathrm{H}^{+}$-ATPase and its assembly factors. Recent technological advances in CDG diagnostics have enabled more comprehensive analysis of glycosylation disorders. Novel mass spectrometric methods to detect changes in glycosylation [72,73] together with next-generation sequencing to detect novel genomic mutations $[74,75]$ are a powerful combination for the interrogation of membrane trafficking components in CDGs. This review serves to provide a comprehensive overview of trafficking-related CDGs and to form a detailed understanding of how Golgi trafficking influences glycosylation.

\section{Membrane Trafficking Components in CDG}

Efficient membrane trafficking is of utmost importance for the entire secretory pathway. In this review, we focus on disorders directly affecting Golgi function. Therefore, other disorders affecting for instance ER to ERGIC transport will not be discussed.

\subsection{Vacuolar $H^{+}$-ATPase}

For efficient delivery of glycosylation enzymes to Golgi cisternae to occur, the intraorganellar $\mathrm{pH}$ must allow the association of the glycosylation enzyme with a trafficking cargo receptor at the donor compartment and release from the receptor at the receiving compartment. Given the role of $\mathrm{pH}$ in intracellular trafficking and how stringent cisternal $\mathrm{pH}$ is regulated in the Golgi apparatus (Figure 2) [51], alterations in $\mathrm{pH}$ maintenance might be expected to lead to mislocalization of glycosylation enzymes, which in turn cause glycosylation disorders. Indeed, genetic variants in $A T P 6 V 0 A 2$, the gene encoding the membrane-bound $\mathrm{V}_{0}$ a2 subunit of the V-ATPase localized to endosomes and TGN [49,50], lead to glycosylation defects [48]. Patients with pathogenic variants, loss-of-function mutations leading to a truncated protein, in ATP6V0A2 present with wrinkly skin syndrome and autosomal recessive cutis laxa type II, both connective tissue disorders related to the secretion of elastin to the extracellular matrix, and neurological involvement. Moreover, experiments in patient fibroblasts with the fungal metabolite Brefeldin A (BFA), which inhibits the formation of COPI vesicles [76], demonstrate that retrograde intra-Golgi trafficking is impaired in pathogenic ATP6V0A2 variants, likely causing the mislocalization of glycosyltransferases. Supporting this, neutralization of the Golgi $\mathrm{pH}$ with the weak base ammonium chloride or proton pump inhibitor Bafilomycin A1 also mislocalizes glycosyltransferases [77]. Furthermore, the misregulation of Golgi pH could influence the delivery of glycosylated cargo via the cargo receptor ERGIC53, which binds high mannose glycans in the ER in a pH-dependent manner and transports them to the Golgi apparatus [24-26,78]. Thus, in addition to the deviation of the $\mathrm{pH}$ values away from those optimal for glycosyltransferase activity, mutations in subunits of the V-ATPase could result in mislocalization of both glycosyltransferases and their substrates, and this likely contributes to the CDG pathology. General $\mathrm{pH}$ maintenance in the Golgi is imperative for physiological glycosylation. 


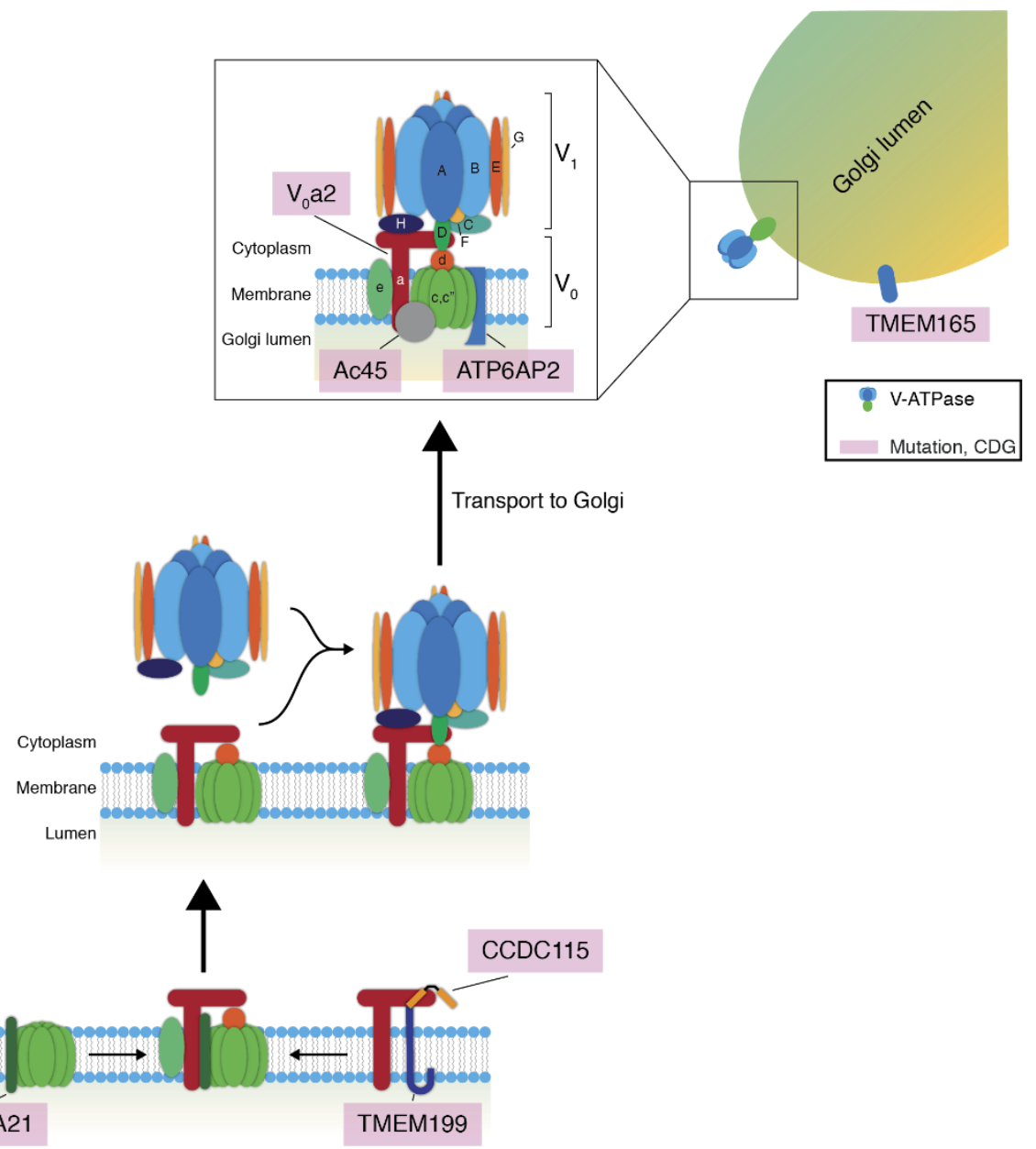

Figure 2. Schematic overview of the mammalian V-ATPase and the putative model of its assembly. Lowercase letters denote the various subunits of the $\mathrm{V}_{0}$-domain; uppercase letters denote the subunits of the $\mathrm{V}_{1}$-domain. The assembly factors VMA21, TMEM199, and CCDC115 might assemble the membrane-associated $V_{0}$-domain of the V-ATPase. VMA21 interacts with $V_{0} c^{\prime}$ and $V_{0}$ a [79-82], TMEM199 and CCDC115 interact with $\mathrm{V}_{0}$ a [83]. Abbreviations: V-ATPase, vacuolar $\mathrm{H}^{+}$-ATPase; CDG, congenital disorder of glycosylation.

Aside from variants in the V-ATPase itself, assembly factors and accessory proteins have also been implicated in CDGs. One accessory protein of the V-ATPase, Ac45 (Figure 2; also known as ATP6AP1, the ortholog of yeast Voa1p), is ubiquitously expressed [84-87] and mainly guides the V-ATPase into cell type-specific subcellular compartments such as neuroendocrine secretory vesicles [88,89] or the ruffled border of osteoclasts [84,90,91]. Missense mutations at sites coding for highly conserved residues in Ac45 have been identified [92] with patients suffering from immunodeficiencies, hepatopathy, neurocognitive abnormalities, and abnormal protein glycosylation. This not only demonstrates that Ac45 is an important factor in (tissue-specific) trafficking of the V-ATPase, but also strengthens the notion that the trafficking of the V-ATPase is imperative for functional protein glycosylation.

Another accessory protein, ATP6AP2 (Figure 2), has also been implicated recently in CDG [93]. While its precise mechanistic role in V-ATPase assembly has not been determined, loss of ATP6AP2 in murine cardiomyocytes, hepatocytes, or podocytes causes a decrease in $\mathrm{V}_{0} \mathrm{a} 1-3$ protein levels, as well as defects in autophagy [94-96]. Patients with missense mutations in ATP6AP2 present protein glycosylation abnormalities with hypogalactosylation and hyposialylation and autophagic defects relating to aberrant lysosomal acidification [93]. This phenotype demonstrates the importance of a functional V-ATPase for both glycosylation and lysosomal function. 
Similarly, recently, a novel CDG involving the putative V-ATPase assembly factor VMA21 (ortholog of yeast Vma21p) was discovered, with patients presenting with a hepatic phenotype with steatosis and hypercholesterolemia [97]. Two mutations causing a premature stop codon and one missense mutation in VMA21 were discovered. Mechanistically, the symptoms of VMA21-CDG patients are the result of impaired lipophagy due to reduced lysosomal acidification, and patients present with a loss of sialic acid and galactose on glycoproteins [97]. In yeast, Vma21p interacts with $V_{0}$ subunit $c^{\prime}$ and thus promotes the assembly of the $V_{0}$ proteolipid subunits into a ring (Figure 2) [79,80]. In mammals, VMA21 can also directly interact with subunit $a$ of the $\mathrm{V}_{0}$ domain, and this interaction is dependent on glycosylation of subunit $a$ (Figure 2) [81,82]. This observation has a two-pronged implication: efficient glycosylation is reliant on the proper assembly of the V-ATPase, and the proper assembly of the V-ATPase is reliant on efficient glycosylation. This could function as a quality control mechanism to abrogate the assembly of a faulty V-ATPase. Most interestingly, in yeast strains lacking Vma21p, the ER-Golgi SNARE Bos1p (ortholog of mammalian GosR2 [98,99]) was completely absent from COPII vesicles [100], strengthening the importance of $\mathrm{pH}$ homeostasis for functional ER-Golgi trafficking.

Furthermore, missense mutations in the gene coding for putative V-ATPase assembly factors uncharacterized transmembrane protein 199 (TMEM199, the ortholog of yeast Vma12p) and coiled-coil-domain containing protein 115 (CCDC115, the ortholog of yeast Vma22p) have also been found in novel CDGs [101,102]. CCDC115 and TMEM199 are hypothesized to assemble the membrane-integral $V_{0}$ domain of the V-ATPase through interactions with subunit $a$ (Figure 2) [83]. In S. cerevisiae, assembly of the $\mathrm{V}_{0}$ domain mediated by Vma21p, Vma12p, and Vma22p occurs at the ER membrane [103-105], after which the $V_{0}$ domain is transported to the Golgi and associates with the $\mathrm{V}_{1}$ domain to form the fully functional V-ATPase complex [40]. In mammals, the exact mechanism of V-ATPase assembly is still unclear, but as TMEM199 and CCDC115 localize to the ER, it is suggested that mammalian V-ATPase assembly is analogous to that in yeast [106]. Pathogenic variants in either protein mainly have a hepatic phenotype similar to VMA21-CDG, although a neurological phenotype is observed for CCDC115-CDG patients. Abnormal glycosylation, mainly the truncation of glycans through the loss of sialylation and galactosylation, is seen for both CDGs. This observation corresponds to the mislocalization of especially trans-Golgi-resident galactosyltransferases, which is consistent with the concomitant acidification of the Golgi apparatus. In contrast to VMA21-CDG [97], but in line with ATP6V0A2-CDG [48], no disorders in autophagy were described for TMEM199-CDG and CCDC115-CDG [101,102]. One explanation is that a potential lysosomal defect was not investigated. Another plausible explanation for this phenomenon is that TMEM199 and CCDC115 participate in the assembly of a specific V-ATPase for the Golgi apparatus, while the lysosomal V-ATPase is still assembled regularly in TMEM199-CDG and CCDC115-CDG. This raises the possibility that TMEM199 and CCDC115 primarily interact with a certain $\mathrm{V}_{0}$ a subunit, likely $\mathrm{V}_{0} \mathrm{a} 2$ concerning the glycosylation phenotypes in TMEM199-CDG and CCDC115-CDG, to facilitate the assembly of a Golgi-specific V-ATPase [107-109]. The severity of the symptoms of ATP6AP1-CDG, ATP6AP2-CDG, and VMA21-CDG patients could stem from a more general role of these factors in V-ATPase assembly. Incomplete assembly of the V-ATPase might also result in mislocalization of the $\mathrm{V}_{0}$ domain, as the trafficking of the $\mathrm{V}_{0}$ domain might be $\mathrm{pH}$ dependent itself, thereby amplifying the phenotypes. Aside from their role in CDG, TMEM199 and CCDC115 have also been implicated in iron metabolism [106] and influenza A virus infection, most probably via a pH-dependent mechanism [110]. These observations underpin how V-ATPase assembly, glycosylation, ER-to-Golgi, and intra-Golgi trafficking are intertwined.

Finally, pathogenic variants in the uncharacterized transmembrane protein 165 (TMEM165, also known as TPARL) leading to CDG have been identified [111], one intronic mutation in the gene coding for TMEM165 leading to the production of a truncated protein and two missense mutations at sites coding for highly conserved residues. Patients with TMEM165-CDG mainly present with skeletal and hepatic abnormalities and an N-glycosylation defect consisting of hyposialylation and hypogalactosylation. No O-glycosylation abnormalities were observed in these patients. TMEM165 is a putative proton 
pump, based on protein sequence homology [111], primarily localizing to the late Golgi apparatus and potentially maintaining the $\mathrm{pH}$ in this compartment (Figure 2). This theory is corroborated by the similar glycosylation defects observed with TMEM165-CDG and V-ATPase-related CDGs discussed above. Additionally, depletion of TMEM165 using RNA interference in HEK293 cells revealed a defect in Golgi galactosylation, which could be rescued by supplementation with manganese [112]. As manganese is required for the proper functioning of some glycosylation enzymes [113,114], TMEM165 may also be required for manganese homeostasis, perhaps by functioning as a manganese transporter.

\subsection{Golgins, GRASPs, GORAB, and Rabs}

Vesicle fusion with the Golgi apparatus is initiated by specific capture of vesicles by long coiled-coil proteins decorating the Golgi membrane: Golgins [57-59,115]. Next to this, Golgins also act as structural proteins to maintain Golgi architecture [116]. To date, genetic variants in several Golgins have been identified that affect both retrograde intra-Golgi trafficking and glycosylation. For instance, a nonsense mutation in the gene coding for GMAP-210 (Figure 3, also known as TRIP11) causes neonatal lethal skeletal dysplasia in both mice and humans [117]. Similar to GORAB (see below), the phenotypes in patients carrying loss-of-function mutations in TRIP11 are caused by defective glycosylation of extracellular matrix proteins. GMAP-210 normally functions as a tether for both ER-to-Golgi and intra-Golgi vesicles $[118,119]$. TRIP11 mutant chondrocytes and osteoblasts isolated from mice carrying this nonsense mutation showed swollen ER and a disrupted Golgi architecture. Patient fibroblasts with either a heterozygous or homozygous nonsense variant of GMAP-210 showed incomplete glycosylation of the model secretory protein vesicular stomatitis virus G protein (VSVG) fused to GFP, suggesting a function of GMAP-210 in trafficking. These mutant cells also showed increased lectin GS-II binding along cell surfaces, indicating a defect in glycosylation due to GMAP-210 loss-of-function, as lectin GS-II binds to terminal non-reducing N-acetyl-D-glucosamine, which is normally not present in fully processed glycoproteins [117]. Hypomorphic mutations, or partial loss-of-function mutations, in TRIP11 cause a different genetic disorder called odontochondrodysplasia (ODCD) [120], affecting skeletal and dental development. In contrast to the loss-of-function mutations in TRIP11, secretion is not affected in ODCD. Glycans on the lysosomal glycoprotein LAMP2 and the extracellular matrix protein decorin were both abnormal, and synthesis of extracellular matrix proteins was strongly reduced, leading to disease [120].

Other Golgins also regulate glycosylation, but have not been associated with CDGs. An intronic splice donor site mutation in the gene coding for Golgin giantin (Figure 3, also known as GOLGB1) produces a truncated protein, which causes cleft palate in mice, with murine embryos showing an increase in GS-II lectin binding to terminal GlcNAc moieties within the palatal regions, which is indicative of incomplete protein glycosylation. In parallel, frontal sections of developing palatal shelves of giantin loss-of-function mutant mice show increased binding of PNA lectin after desialylation with neuraminidase, showing an increase in galactosylated O-type mucins on the cell surface [121]. In addition to giantin, certain membrane tethering proteins, such as giantin, GRASP55, and GRASP65 (Figure 3), are thought to regulate the rate of retrograde trafficking, likely to assure efficient recycling of glycosylation enzymes to their target Golgi compartment. RNA interference-mediated depletion of giantin in HeLa cells revealed that this causes aberrant fusion of Golgi cisternae [122]. This, in turn, caused a two-fold increase in the mobility of the glycosylation enzyme ManII as measured by fluorescence recovery after photobleaching and accelerated the trafficking of VSVG to the plasma membrane [123]. Furthermore, siRNA depletion of giantin caused overexpression of sialylated glycoproteins at the cell surface [123]. Moreover, depletion by RNA interference of GRASP55/65 accelerated the anterograde trafficking of VSVG, independent of ER stress and unconventional protein secretion, and concurrently decreased the complete glycosylation of VSVG [124]. 


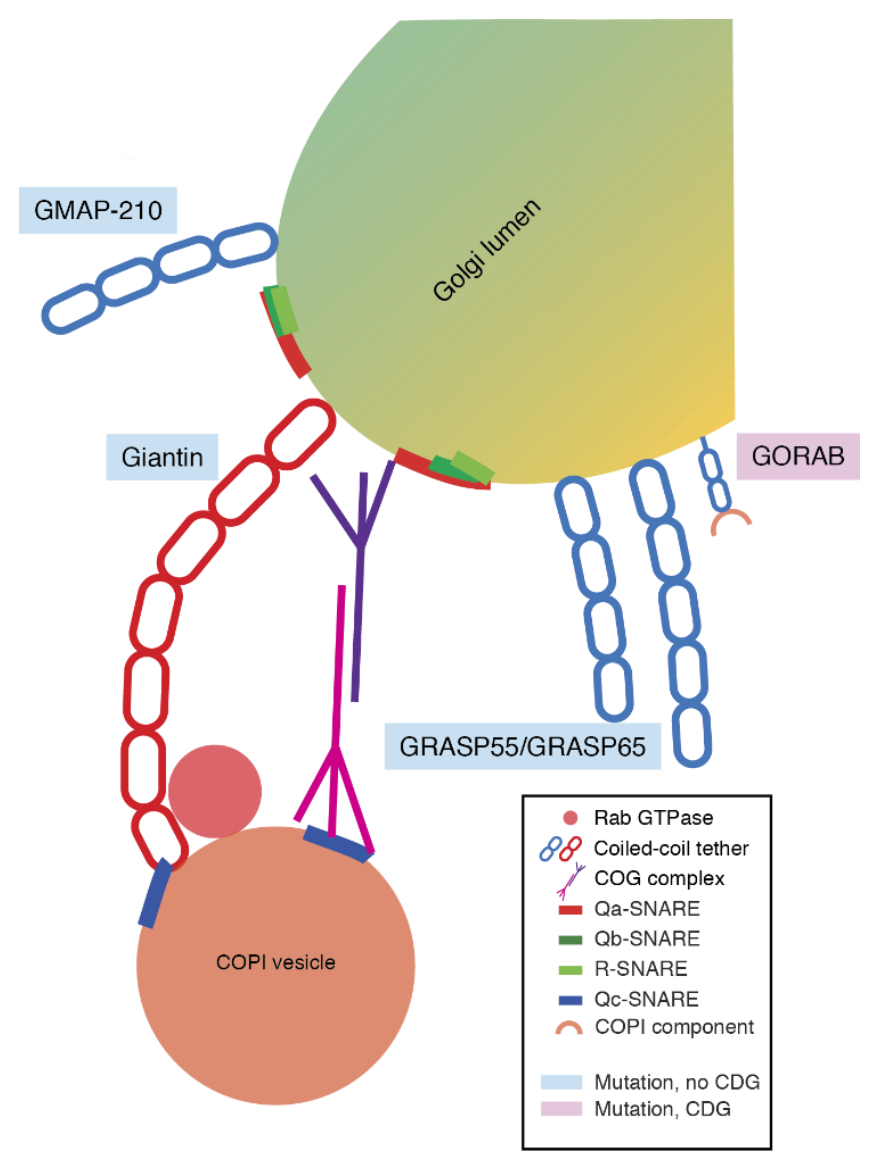

Figure 3. Schematic overview of COPI vesicle capture by coiled-coil tethering proteins at the Golgi. Tentacular coiled-coil proteins attached to the Golgi membrane can capture COPI vesicles to direct them to the Golgi. Abbreviations: CDG, congenital disorder of glycosylation; COG complex, conserved oligomeric Golgi complex; COPI, coat protein complex I; SNARE, soluble N-ethylmaleimide-sensitive factor attachment protein receptor.

More recently, several missense and nonsense mutations in GORAB have been identified in patients (Figure 3). Although GORAB was previously described to be a Golgin, it is now understood that it is a COPI vesicle coat scaffolding protein that likely engages in vesicle formation and has been associated with the development of the skin and bone disorder gerodermia osteodysplastica (GO) [125-128]. GO presents with osteoporosis and has a similar elastin deficiency as cutis laxa [129,130]. Importantly, patients have deficient glycosylation of proteoglycans including decorin and biglycan, leading to their pathologies. GORAB is primarily functional at late stages of intra-Golgi trafficking. GORAB promotes COPI recruitment to the trans-Golgi through the formation of stable membrane domains. GORAB also scaffolds the catalytically inactive protein kinase Scyl1 [125]. Scyl1 localizes to the ERGIC and cis-Golgi budding sites and binds to COPI coats using a C-terminal RKLD sequence, similar to the KKXX COPI-binding motif present in ER transmembrane proteins. The depletion of Scyl1 in HeLa cells by RNA interference disrupts COPI-mediated retrograde trafficking of the KDEL receptor towards the ER [131]. Several missense and nonsense mutations in SCYL1 have been described, but, in contrast to GORAB, primarily hepatological and neurological phenotypes were observed [132-134]. Cellular investigations of patient fibroblasts show an enlarged Golgi morphology as shown by immunofluorescence and impaired retrograde trafficking when perturbed with BFA [132]. Most interestingly, one patient demonstrated hyposialylation of both transferrin and apolipoprotein CIII as measured by isoelectric focusing (IEF) during a liver crisis, but this returned to normal after the crisis had passed [132]. An explanation for this might be that the secretory burden of glycoproteins in this patient was too high during the crisis, leading to abnormal glycosylation. Pathogenic variants in GORAB either affect 
the binding affinity of GORAB to Scyl1 or affect the assembly of GORAB in membrane domains, leading to the dysfunction of GORAB. Loss-of-function mutations in GORAB inhibit the retrieval of trans-Golgi resident enzyme ST6GAL1 in a COPI-mediated manner, demonstrating the necessity of GORAB for COPI-mediated intra-Golgi trafficking. Concurrently, GORAB mutant fibroblasts from GO patients show a reduced abundance of complex terminally sialylated glycans, suggesting deficient glycosylation by dysfunctional GORAB [125]. Taken together, the observed phenotypes suggest that GORAB mutations can be considered CDGs.

Once a vesicle has been captured by a Golgin, effectors such as Rab GTPases are recruited (Figure 3). Rabs exists in a GDP-bound inactive state and are activated by the exchange for GTP through guanine nucleotide exchange factors (GEFs). This nucleotide exchange results in a conformation switch, which enables Rabs to recruit specific effectors required for vesicular trafficking. Genetic variants within Rab proteins are associated with several neurological and metabolic disorders, including Parkinson's disease and Neumann-Pick's disease [135]. Certain Rabs play an active role in retrograde Golgi trafficking, such as Rab6, which is required for bidirectional transport of cargo at the Golgi [64]. Furthermore, Rab2 can influence the function of GMAP-210 in COPI vesicle tethering [119], while Rab1, Rab2, Rab4, and Rab6 can interact with members of the COG complex and thereby tether COPI vesicles to the Golgi membrane [136]. Rab1, in particular, has also been identified to regulate the Golgi architecture and function and therefore has an indispensable role in glycosylation [135]. While genetic variants in Rabs or their regulatory proteins have not been implicated in CDGs thus far, it is conceivable that Rab dysfunction alters the identity of COPI vesicles, which results in the mislocalization of glycosylation enzymes. Thus, considering the potential effects of Rab dysfunction on glycosylation, it stands to reason that Rab CDGs are yet to be identified.

\subsection{Conserved Oligomeric Golgi Tethering Complex}

After Golgins mediate the capture of Golgi-destined vesicles from the cytosol, the COG complex functions as a tether to anchor COPI vesicles to the Golgi membrane [137-139]. COG subunits have been described to interact directly with COPI coat components, as well as with SNAREs and Rab GTPases involved in Golgi trafficking [68,140-145]. Despite the lack of transmembrane domains in COG subunits, they are membrane-associated proteins. The COG complex is a hetero-octameric protein complex, consisting of eight unique subunits COG1-8 (Figure 4). These subunits organize themselves into two distinct lobes: lobe A consisting of COG1-4 and lobe B consisting of COG5-8. This in turn also dictates their localization: lobe $\mathrm{A}$ is primarily present on the Golgi membrane, while lobe $\mathrm{B}$ localizes to COPI vesicles [145]. The two lobes are bridged by an interaction between COG1 and COG8 through the formation of alpha-helical bundles $[68,140]$. The COG complex is therefore required for the trafficking of glycosyltransferases and cargo proteins.

Cellular models of COG-subunit deficiencies show an alteration in glycosylation homeostasis [146]. At a cellular level, the depletion of COG subunits 2, 3, 4, 6, 7, and 8 causes the mislocalization of glycosylation enzymes MAN2A1, MGAT1, B4GALT1, and ST6GAL1 to COG complex-dependent vesicles [147,148], demonstrating their necessity in functional glycosylation [149]. Studies in HeLa cells depleted of COG4 by RNA interference also demonstrated glycosylation defects and the mislocalization of vesicles containing COG-interacting proteins (GEARs) around the Golgi $[138,140,148]$. Of note, the permanent membrane targeting of COG subunits 4,7 , and 8 by fusing them to the transmembrane protein TMEM115 [150] disrupts the ribbon structure of the Golgi as visualized by electron microscopy, causing the swelling of cisternae and an increase of spherical, non-cisternal elements [151]. Nevertheless, membrane-anchoring of COG4 and COG7, but not COG8, rescued the glycosylation defects observed in their respective CRISPR/Cas 9 knockout cell models. The N-terminal attachment of membrane-anchored COG8 interfered with overall COG structure and function, impeding the rescue of the observed glycosylation defects [151]. The permanent Golgi anchoring of COG4 and 7 maintains the polarization of cis- and trans-Golgi markers, but fails to restore a highly organized Golgi structure in COG4 and 7 knockout cells. These data demonstrate that the membrane association of most COG subunits is 
imperative for their function, and likely assists in the correct retrieval of glycosyltransferases to earlier Golgi cisternae.

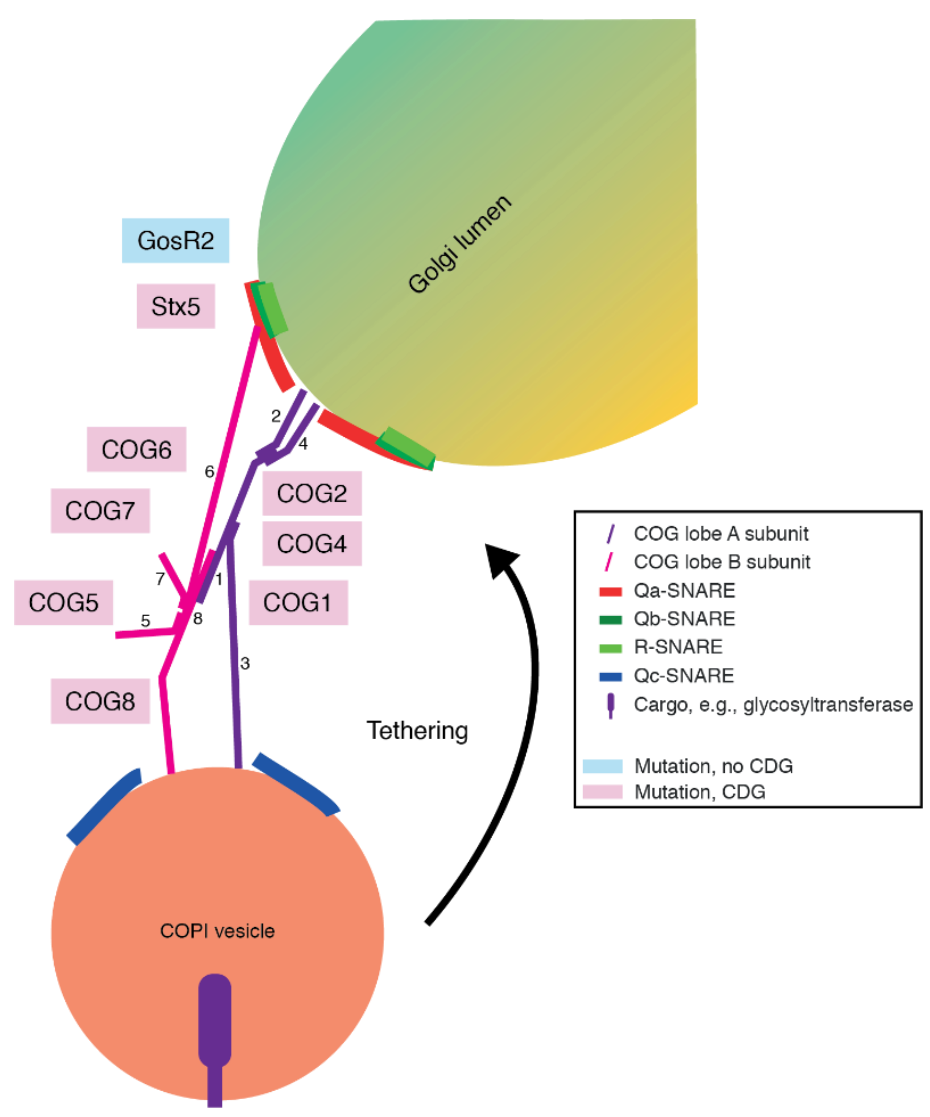

Figure 4. Schematic overview of COG-mediated vesicle tethering and SNARE-mediated vesicle fusion at the Golgi. COPI vesicles are tethered to the Golgi membrane through the interaction of COG lobes A and B. Subsequently, SNARE-mediated membrane fusion occurs, and the vesicle cargo is released to the Golgi lumen. Abbreviations: CDG, congenital disorder of glycosylation; COG complex, conserved oligomeric Golgi complex; COPI, coat protein I; SNARE, soluble N-ethylmaleimide-sensitive factor attachment protein receptor.

Genetic variants causing CDGs have been identified for all COG subunits, except for COG3 [140, 149,152]. Most genetic variants in COG subunits are observed in lobe A subunits COG1 and COG4 and in lobe B subunit COG8 (Figure 4). While in most CDGs, $\mathrm{N}$-glycosylation is mostly affected, COG-CDGs show a broader phenotype with defects in both $\mathrm{N}$ - and O-glycan biosynthesis [149]. Clinically, patients of COG-CDGs present with prominent incomplete galactosylation and sialylation $[149,153]$, and this is true for variants in both lobe $\mathrm{A}$ and $\mathrm{B}$ subunits. While the variants mostly consist of missense mutations or truncations for lobe A subunits and full loss-of-function mutations in lobe B subunits, glycan profiles of patients show the same hypogalactosylation and hyposialylation for both types of mutations [154,155]. This raises the question of whether mutations in one COG subunit affect the entire COG complex. Indeed, a variant in one COG subunit is associated with the instability of another subunit within that lobe, leading to the decrease in protein expression of subunits in the same lobe [156]. This has been shown for COG1 [153] and COG2 [152] in lobe A and COG6, COG7 [157,158], and COG8 [159] for lobe B. Moreover, the mutations in COG1 are associated with a decrease in protein levels of COG8 [153]. Oppositely, a truncation mutant of COG8 also decreases the protein levels of COG1 [160]. The finding that all eight subunits are required for complete COG function is a possible explanation for the similarity in glycan profiles of COG-CDGs (see below). However, COG1- and 
COG4-CDG phenotypes are relatively mild, while COG7- and COG8-CDG are much more severe. This could indicate a differential necessity of COG lobe B over lobe A.

COG-CDGs have mainly been implicated through genetic variants of COG1 and COG4 for lobe A. Patients with an 80 residue C-terminal truncation of COG1 present with a reduction of galactose and sialic acid moieties on $\mathrm{N}$ - and O-glycans. Consistent with this, fibroblasts isolated from these patients demonstrate a reduction of sialic acid incorporation on mucin-type O-glycans [153]. A different variant, an intronic mutation that results in a frameshift and a premature stop codon in exon 7, in COG1 causes skeletal defects and mental retardation, together with hypogalactosylation and hyposialylation [161]. Moreover, the Brefeldin A assay performed on these patient fibroblasts revealed a retrograde Golgi trafficking defect. In $\mathrm{CHO}$ cells, depletion of COG1 by RNA interference leads to both deficient $\mathrm{N}$ - and O-glycosylation [138,140]. Fibroblasts from a patient with two heterozygous missense and nonsense mutations, respectively, in COG4 also showed hypogalactosylation and hyposialylation [162,163]. Effects of these variants on other COG subunits were not investigated. Moreover, a patient with a different missense mutation in COG4 presented with a similar glycosylation defect, but the instability of the other subunits in COG lobe A was also observed, likely due to the inability to form COG subcomplexes [164]. Lastly, another amino acid substitution in COG4 was identified causing a rare form of primordial dwarfism, but patients notably have normal glycosylation of serum proteins [165]. Instead, the extracellular matrix protein decorin is abnormally glycated in these patients, underlying their pathology.

To date, only a single mutation, an intronic mutation leading to a decrease in COG5 expression, has been identified in the gene coding for COG lobe B subunit COG5 with mostly neurological symptoms and similar hypogalactosylation and hyposialylation like in other COG defects [154,166-168]. Several studies have shown that a single missense mutation in COG6 leads to severe neurological and hepatological symptoms and can lead to infant mortality [169-172]. The relative severity of COG6-CDG is likely due to the observed instability of COG lobe B, as COG6-CDG patients also have lower protein levels of COG5 and COG7. Furthermore, decreased levels of the trans-Golgi SNARE syntaxin-6 were detected, suggesting that stabilization of syntaxin- 6 via the COG complex is necessary for its function [171]. Intronic mutations affecting the mRNA splicing and ultimately causing the decrease of protein levels of COG7 cause similar glycosylation defects, with patients presenting hyposialylation in their N- and O-linked glycan biosynthesis $[157,158,173]$. Another study observed that one specific variant in COG7, which is associated with infantile mortality [174], causes a loss of sialylation on serum transferrin and on cell surface proteins of patient fibroblasts [175]. Moreover, this variant in COG7 affects Golgi trafficking as shown by the impaired trafficking of ST3GAL1 from the ER to the trans-Golgi in patient fibroblasts. A homozygous nonsense mutation in COG8 results in the formation of a truncated COG8 subunit, lacking 76 C-terminal residues, affecting the interaction between COG8 and COG1. Patients with this variant present with mild hyposialylation [160]. Similarly, a patient with a different genetic variant resulting in the truncation of COG8 with the loss of 47 C-terminal residues showed a similar deficiency in sialylation [159]. COG8-CDG patients present with a severe neurological phenotype and display a fragmented Golgi apparatus in patient fibroblasts. Overall, the COG defects demonstrate the importance of efficient tethering of intra-Golgi vesicles and show that even small changes are enough to destabilize the COG complex, thereby severely affecting glycosylation.

\subsection{SNARES}

The final step in the delivery of glycosylation enzymes to the Golgi is SNARE-mediated membrane fusion. SNARE proteins are classified by the central residue in their SNARE motif: R-SNAREs have a central arginine residue, while Qa-, Qb-, Qbc-, and Qc-SNAREs have a central glutamine residue. A tight alpha-helical coiled-coil bundle is formed by one of each type of SNARE motif, provided by three or four cognate SNARE proteins. These are present on both the vesicular (e.g., COPI vesicle) and target membranes (e.g., cis-Golgi), and the coiled-coil formation provides enough energy to fuse the two opposing membranes [176,177]. At the mammalian ER-Golgi interface, four distinct 
SNARE complexes exist: Stx5/GosR2 (also known as GS27 or membrin)/Bet1/Sec22b (also known as ERS24) for anterograde transport from ER to ERGIC, Stx5/GosR1/Bet1/Ykt6 for anterograde transport from ERGIC to cis-Golgi, Stx5/GosR1 (also known as GS28)/Bet1L (also known as GS15)/Ykt6 for retrograde intra-Golgi transport, and Stx18/Sec20/Use1/Sec22b for retrograde transport from cis-Golgi to ER $[98,99,178-191]$. While in general, R-SNAREs are present on the vesicular membrane in eukaryotic cells [177], evidence suggests that the Qc-SNAREs Bet1 and Bet1L function as the vesicular SNAREs at the ER-Golgi interface $[99,188,191-194]$. This observation, together with the necessity of Sec1/Munc18 SM) protein Scfd1 in ER-Golgi SNARE fusion, likely implies specificity to the fusogenic SNARE complex, by inhibiting the formation of non-functional SNARE complexes [30,195-198].

Despite the essential role of SNAREs in Golgi trafficking [99], there is only limited evidence for a clinical link between glycosylation and genetic variants in SNARE proteins. This also raises the question of whether SNARE CDGs mostly remain undetected due to a possible severity of the disease. Contrary to plasma membrane-localized SNARE complexes, ER-Golgi-localized SNARE complexes lack redundancy, and the loss of a single SNARE protein at this interface might result in detrimental effects for glycosylation and/or life [98]. Recently, the first CDG related to a SNARE protein was identified, namely a point mutation in STX5, the gene coding for the Qa-SNARE syntaxin-5 [191]. In animals, the STX5 gene is transcribed to one mRNA, which produces two different isoforms of Stx 5 via an alternative starting codon: $39.6 \mathrm{kDa}$ sized Stx5 Long (Stx5L) and $34.1 \mathrm{kDa}$ sized Stx5 Short (Stx5S) $[99,199]$. Stx5L is characterized by a 54 residue N-terminal extension with an RKR (arginine-lysine-arginine) ER-retrieval motif and localizes at ER, ERGIC, and cis-Golgi. In contrast, Stx5S lacks this RKR ER-retrieval motif and primarily localizes to the Golgi (Figure 4). The point mutation causes the specific loss of Stx5S through the mutation of the second starting methionine residue into valine. This loss of the intra-Golgi dominant Qa-SNARE Stx5S results in a severe disorder, characterized by metabolic and developmental defects and infantile mortality. Microscopy revealed that this is caused by the mislocalization of glycosylation enzymes to the wrong compartment in the Golgi apparatus, leading to the reduced incorporation of galactose and sialic acid moieties in $\mathrm{N}$-glycans and an overrepresentation of immature high-mannose glycans [191].

The Qbc-SNARE SNAP29 has previously also been ascribed a role in Golgi morphology, and its dysfunction could likely result in glycosylation defects [200]. Of note, several missense and truncating mutations in SNAP29 have been associated with cerebral dysgenesis, neuropathy, ichthyosis, and keratoderma syndrome (CEDNIK, a disorder of brain development, facial dysmorphism, and skin), and Pelizaeus-Merzbacher-like disorder (PMLD, a disorder of brain development and muscle function) [201-207]. The first report of SNAP29 involvement in CEDNIK noted that no N- and O-glycosylation defects were observed, although the authors did not describe how the patients were screened [206]. This result does not exclude that SNAP29 is involved in glycosylation, as, assuming that custom IEF methods were applied for CDG screening, it is possible that although glycosylation of either transferrin or apolipoprotein CIII were not affected, other glycosylated proteins were. Additionally, these methods might not have been sensitive enough to detect an underlying glycosylation disorder, or only glycosylation in certain tissues could have been affected. Finally, fusion-impaired forms of GosR2 result in a neurological phenotype in patients with progressive myoclonus epilepsy, but have not been associated with glycosylation defects (Figure 4) [208-210]. It is possible that during these studies, no diagnostics for glycosylation has been performed or that through a compensatory mechanism, sufficient glycosylation was maintained. Along these lines, more comprehensive diagnostic screening procedures might implicate more SNAREs in CDGs.

\section{Discussion and Conclusions}

The glycosylation process is an essential part of the secretory pathway and is a complex logistic system. Newly synthesized glycoproteins are shuttled from the ER to the Golgi apparatus, which acts as a production line that sequentially builds complex branched glycan structures on the proteins. Moreover, the Golgi can be considered a distribution center that ensures that glycoproteins are modified 
and sorted correctly to their final destinations. As with factories and other logistic systems, having efficient infrastructure is the key to a high efficiency and fidelity of production and delivery. Each organelle in the logistic chain needs to function optimally to avoid bottlenecks, and therefore, efficient coordination amongst organelles is of utmost importance. Here, we discussed how dysfunctional transport processes affect glycosylation and, in turn, cause a wide array of symptoms including skin and bone disorders, impaired liver function, and even infantile mortality. Mechanistically, these pathologies are the result of impaired $\mathrm{pH}$ homeostasis in the Golgi, incorrect tethering of Golgi-destined vesicles, and defective membrane fusion at the Golgi apparatus (Table 1).

In this review, we discussed pathogenic variants in the V-ATPase and associated proteins that affect Golgi $\mathrm{pH}$ homeostasis and glycosylation. Considering that glycosylation enzymes have a broad $\mathrm{pH}$ optimum and that the Golgi has a narrow range in $\mathrm{pH}$ (pH 6.7 for cis to $\mathrm{pH} 6.0$ for trans), it seems unlikely that small defects in $\mathrm{pH}$ homeostasis result in a pronounced loss of catalytic activity of the glycosylation enzymes. Instead, the prevailing theory is that $\mathrm{pH}$ affects the trafficking of glycosylation enzymes to their cognate Golgi compartments and that altering the Golgi $\mathrm{pH}$ results in mislocalization of these enzymes to the wrong compartment [53-55]. This is corroborated by the observation that Golgi-to-ER recycling mediated by the KDEL receptor is indeed pH-dependent [211] and by the observation that the ER-Golgi SNARE protein Bos1p is absent from COPII vesicles of yeast strains lacking the V-ATPase assembly factor Vma21p [100]. Moreover, it has been described that the luminal $\mathrm{pH}$ affects the oligomerization of certain glycosylation enzymes and thereby also influences their localization [212-219]. Another well-characterized example of $\mathrm{pH}$-mediated protein sorting is the binding of the mannose-6-phosphate receptor to the mannose-6-phosphate-labeled cargo destined for the lysosome. Proteins are bound by this receptor in the Golgi and subsequently released in the more acidic environment of late endosomes [220-222]. Finally, the pH of the TGN is also important for the correct sorting of the extracellular matrix components laminin and heparan sulfate proteoglycan to the basolateral surface of polarized epithelial cells $[220,223,224]$. Taken together, evidence shows that homeostasis of $\mathrm{pH}$ is of crucial importance for trafficking within, from, and to the Golgi apparatus, and thereby likely a critical factor for glycosylation. This also implicates that mislocalization of the V-ATPase and associated proteins due to pathogenic mutations in trafficking proteins such as SNAREs, COG subunits, or Golgins can affect glycosylation. 
Table 1. Overview of membrane trafficking-related CDGs and their phenotypes.

\begin{tabular}{|c|c|c|c|c|c|c|c|c|c|c|c|}
\hline Gene & Mutation & $\mathrm{CDG}^{\mathrm{a}}$ & $\begin{array}{c}\text { Clinical } \\
\text { Phenotype }\end{array}$ & N-Glycosylation ${ }^{c}$ & Man & GlcNAc & Gal & Sia & O-Glycosylation ${ }^{c}$ & Screening ${ }^{d}$ & References \\
\hline ATP6V0A2 & V66fsX107 & $x$ & + & --- & $=$ & $=$ & - & -- & -- & IEF, MS & [48] \\
\hline ATP 6 V0A2 & T643fsX683 & $x$ & + & --- & $=$ & $=$ & - & -- & n.d. & IEF & [48] \\
\hline ATP 6 V0A2 & Q765X & $X$ & + & --- & $=$ & $=$ & - & -- & -- & IEF, MS & [48] \\
\hline ATP6V0A2 & R63X & $x$ & ++ & --- & $=$ & $=$ & - & -- & -- & IEF, MS & {$[48,225]$} \\
\hline ATP 6 V0A2 & K117fsX144 & $x$ & ++ & --- & $=$ & $=$ & - & -- & -- & IEF, MS & {$[48,225]$} \\
\hline ATP6V0A2 & n.d. & $x$ & ++ & --- & $=$ & $=$ & - & -- & -- & IEF, MS & {$[48,225]$} \\
\hline ATP 6 V0A2 & D243fsX258 and E442fsX506 & $X$ & ++ & --- & $=$ & $=$ & - & -- & $=$ & IEF, MS & [48] \\
\hline ATP 6 V0A2 & T280fsX285 & $x$ & +++ & --- & $=$ & $=$ & - & -- & -- & IEF, MS & [48] \\
\hline ATP 6 V0A2 & E442X & $x$ & +++ & --- & $=$ & $=$ & - & -- & $=$ & IEF, MS & {$[48]$} \\
\hline ATP6AP1 & M4281 & $X$ & + & --- & $=$ & $=$ & -- & -- & -- & IEF, MS & [92] \\
\hline ATP6AP1 & L144P & $x$ & + & --- & $=$ & $=$ & -- & -- & -- & IEF, MS & [92] \\
\hline ATP6AP1 & E346K & $x$ & ++ & --- & $=$ & $=$ & -- & -- & -- & IEF, MS & [92] \\
\hline ATP6AP1 & $\mathrm{Y} 313 \mathrm{C}$ & $x$ & ++ & --- & $=$ & $=$ & -- & -- & -- & IEF, MS & [92] \\
\hline ATP6AP2 & L98S & $x$ & ++ & --- & $=$ & $=$ & -- & -- & $=$ & CZE, IEF, MS & [93] \\
\hline ATP6AP2 & L98S & $X$ & + & --- & $=$ & $=$ & -- & -- & $=$ & CZE, IEF, MS & [93] \\
\hline ATP6AP2 & $\mathrm{R} 71 \mathrm{H}$ & $x$ & ++ & --- & $=$ & $=$ & -- & -- & $=$ & CZE, IEF, MS & [93] \\
\hline VMA21 & n.d. ${ }^{1}$ & $X$ & + & -- & $=$ & $=$ & -- & -- & - & IEF, MS & [97] \\
\hline$V M A 21$ & $\mathrm{R} 18 \mathrm{G}^{*}$ & $X$ & + & -- & $=$ & $=$ & -- & -- & - & IEF, MS & [97] \\
\hline$V M A 21$ & N63G & $x$ & + & -- & $=$ & $=$ & -- & -- & - & IEF, MS & [97] \\
\hline TMEM199 & A7E & $X$ & + & --- & $=$ & $=$ & - & - & --- & IEF, MS & {$[102]$} \\
\hline TMEM199 & $\mathrm{A} 14 \mathrm{P}$ & $X$ & + & --- & $=$ & $=$ & - & - & $=$ & IEF, MS & [102] \\
\hline TMEM199 & R31P & $X$ & + & --- & $=$ & $=$ & - & - & --- & IEF, MS & [102] \\
\hline CCDC115 & L31S & $x$ & ++ & --- & $=$ & $=$ & -- & -- & --- & IEF, MS & [101] \\
\hline$C C D C 115$ & D11Y & $x$ & ++ & --- & $=$ & $=$ & -- & -- & --- & IEF, MS & [101] \\
\hline TMEM165 & n.d. ${ }^{2}$ & $x$ & ++ & --- & $=$ & $=$ & -- & -- & $=$ & IEF, MS, L & [111] \\
\hline TMEM165 & $\mathrm{R} 126 \mathrm{C}$ & $x$ & ++ & --- & $=$ & $=$ & -- & -- & $=$ & IEF, MS, L & [111] \\
\hline TMEM165 & R126C and G304R & $x$ & + & --- & $=$ & $=$ & -- & -- & & IEF, MS, L & [111] \\
\hline GMAP-210 & L1668X & - & +++ & --- & $=$ & $=$ & -- & -- & $=$ & $\mathrm{L}$ & {$[117]$} \\
\hline GMAP-210 & G439VfsX20 and n.d. ${ }^{4}$ & - & +++ & n.d. & n.d. & n.d. & n.d. & n.d. & n.d. & Blot & {$[120]$} \\
\hline GMAP-210 & D410Y and E1606LfsX3 & - & +++ & n.d. & n.d. & n.d. & n.d. & n.d. & n.d. & Blot & {$[120]$} \\
\hline GMAP-210 & Q196X and Q1512X & - & +++ & n.d. & n.d. & n.d. & n.d. & n.d. & n.d. & Blot & {$[120]$} \\
\hline GMAP-210 & D410Y and I710CfsX19 & - & +++ & n.d. & n.d. & n.d. & n.d. & n.d. & n.d. & Blot & {$[120]$} \\
\hline GMAP-210 & K541RfsX17 and M1806V & - & +++ & n.d. & n.d. & n.d. & n.d. & n.d. & n.d. & Blot & {$[120]$} \\
\hline GMAP-210 & Q196X and K998SfsX5 & - & +++ & n.d. & n.d. & n.d. & n.d. & n.d. & n.d. & Blot & {$[120]$} \\
\hline GMAP-210 & Q196X and R264X & - & +++ & n.d. & n.d. & n.d. & n.d. & n.d. & n.d. & Blot & {$[120]$} \\
\hline
\end{tabular}


Table 1. Cont.

\begin{tabular}{|c|c|c|c|c|c|c|c|c|c|c|c|}
\hline Gene & Mutation & $\mathrm{CDG}^{\mathrm{a}}$ & $\begin{array}{c}\text { Clinical } \\
\text { Phenotype }\end{array}$ & N-Glycosylation ${ }^{c}$ & Man & GlcNAc & Gal & Sia & O-Glycosylation ${ }^{c}$ & Screening ${ }^{d}$ & References \\
\hline GOLGB1 & n.d. ${ }^{3}$ & - & ++ & --- & $=$ & $=$ & -- & -- & --- & $\mathrm{L}$ & [121] \\
\hline GORAB & F8L & - & ++ & --- & $=$ & $=$ & $=$ & -- & $=$ & MS, L & [125] \\
\hline$G O R A B$ & K190del & - & ++ & --- & $=$ & $=$ & $=$ & -- & $=$ & MS, L & [125] \\
\hline GORAB & M1? & $x$ & ++ & $=$ & $=$ & $=$ & $=$ & $=$ & $=$ & CZE & {$[127,226]$} \\
\hline$G O R A B$ & $\mathrm{E} 46 \mathrm{X}$ & $x$ & ++ & n.d. & $=$ & $=$ & $=$ & $=$ & n.d. & n.d. & [127] \\
\hline GORAB & P86RfsX70 & $x$ & ++ & n.d. & $=$ & $=$ & $=$ & $=$ & n.d. & n.d. & [127] \\
\hline GORAB & E123X & $x$ & ++ & n.d. & $=$ & $=$ & $=$ & $=$ & n.d. & n.d. & [127] \\
\hline GORAB & S175_R221del & $x$ & ++ & n.d. & $=$ & $=$ & $=$ & $=$ & n.d. & n.d. & [127] \\
\hline GORAB & Q247X & $X$ & ++ & n.d. & $=$ & $=$ & $=$ & $=$ & n.d. & n.d. & [127] \\
\hline$G O R A B$ & $\mathrm{R} 262 \mathrm{X}$ & $X$ & ++ & n.d. & $=$ & $=$ & $=$ & $=$ & n.d. & n.d. & [127] \\
\hline GORAB & F350LfsX26 & $x$ & ++ & n.d. & $=$ & $=$ & $=$ & $=$ & n.d. & n.d. & [127] \\
\hline SCYL1 & H392PfsX30 & - & + & n.d. & n.d. & n.d. & n.d. & n.d. & n.d. & n.d. & [133] \\
\hline SCYL1 & V313CfsX6 and n.d. ${ }^{4}$ & - & + & n.d. & n.d. & n.d. & n.d. & n.d. & n.d. & n.d. & [134] \\
\hline SCYL1 & A504PfsX15 and Q546X & - & + & n.d. & n.d. & n.d. & n.d. & n.d. & n.d. & n.d. & [134] \\
\hline SCYL1 & Q57X & - & + & n.d. & n.d. & n.d. & n.d. & n.d. & n.d. & n.d. & [132] \\
\hline SCYL1 & $\mathrm{E} 86 \mathrm{X}$ & - & + & n.d. & n.d. & n.d. & n.d. & n.d. & n.d. & n.d. & [132] \\
\hline SCYL1 & A105V & - & + & n.d. & n.d. & n.d. & n.d. & n.d. & n.d. & n.d. & [132] \\
\hline SCYL1 & V313CfsX6 and Q347X & - & + & n.d. & n.d. & n.d. & n.d. & n.d. & n.d. & n.d. & [132] \\
\hline SCYL1 & n.d. ${ }^{4}$ & - & + & n.d. & n.d. & n.d. & n.d. & n.d. & n.d. & n.d. & [132] \\
\hline SCYL1 & D478G & - & + & n.d. & n.d. & n.d. & n.d. & n.d. & n.d. & n.d. & [132] \\
\hline SCYL1 & A504PfsX15 & - & + & n.d. & n.d. & n.d. & n.d. & n.d. & n.d. & n.d. & [132] \\
\hline SCYL1 & Q546X & - & + & n.d. & n.d. & n.d. & n.d. & n.d. & n.d. & n.d. & [132] \\
\hline SCYL1 & Q628X & - & + & n.d. & n.d. & n.d. & n.d. & n.d. & n.d. & n.d. & [132] \\
\hline COG1 & $900 X$ & $X$ & ++ & --- & $=$ & $=$ & -- & -- & --- & IEF, MS, L & [153] \\
\hline COG1 & n.d. ${ }^{4}$ & $x$ & ++ & -- & $=$ & $=$ & - & -- & -- & IEF, MS & [161] \\
\hline COG2 & Y234X and W634G & $x$ & +++ & -- & $=$ & $=$ & - & -- & n.d. & IEF, MS & [152] \\
\hline COG4 & L773R & $x$ & ++ & --- & $=$ & $=$ & $=$ & -- & --- & $\begin{array}{c}\text { IEF, HPLC, } \\
\text { MS }\end{array}$ & {$[162,163]$} \\
\hline COG4 & E233X & $x$ & ++ & --- & $=$ & $=$ & $=$ & -- & --- & $\begin{array}{l}\text { IEF, HPLC, } \\
\text { MS }\end{array}$ & {$[162,163]$} \\
\hline COG4 & R729W & $\mathrm{X}$ & ++ & --- & $=$ & $=$ & $=$ & -- & $=$ & IEF, MS & [164] \\
\hline COG4 & G516R & $x$ & ++ & $=$ & $=$ & $=$ & $=$ & $=$ & $=$ & MS & [165] \\
\hline COG5 & n.d. ${ }^{4}$ & $x$ & $+/++$ & -- & + & + & -- & -- & -- & IEF, MS & $\begin{array}{c}{[154,166-} \\
168]\end{array}$ \\
\hline COG6 & G549V & $x$ & +++ & -- & $=$ & $=$ & - & -- & -- & $\begin{array}{c}\text { IEF, HPLC, } \\
\text { MS }\end{array}$ & [169-172] \\
\hline
\end{tabular}


Table 1. Cont.

\begin{tabular}{|c|c|c|c|c|c|c|c|c|c|c|c|}
\hline Gene & Mutation & $\mathrm{CDG}^{\mathrm{a}}$ & $\begin{array}{c}\text { Clinical } \\
\text { Phenotype }\end{array}$ & N-Glycosylation ${ }^{c}$ & Man & GlcNAc & Gal & Sia & O-Glycosylation ${ }^{c}$ & Screening ${ }^{d}$ & References \\
\hline COG7 & n.d. ${ }^{4}$ & $x$ & +++ & --- & $=$ & $=$ & $=$ & -- & --- & IEF, L & $\begin{array}{l}157,158, \\
174,175]\end{array}$ \\
\hline COG7 & n.d. ${ }^{4}$ & $x$ & +++ & -- & $=$ & $=$ & - & -- & -- & IEF, MS & [173] \\
\hline COG8 & Y537X & $x$ & ++ & --- & $=$ & $=$ & - & - & --- & IEF, MS, L & [160] \\
\hline COG8 & F563HfsX4 & $x$ & ++ & --- & $=$ & $=$ & $=$ & - & --- & MS, L & [159] \\
\hline STX5 & M55V & $x$ & +++ & --- & ++ & $=$ & $=$ & -- & --- & IEF, MS, L & [191] \\
\hline SNAP29 & R29X & - & ++ & n.d. & $=$ & $=$ & $=$ & $=$ & n.d. & n.d. & [201] \\
\hline SNAP29 & L119AfsX15 and n.d. ${ }^{4}$ & - & ++ & n.d. & $=$ & $=$ & $=$ & $=$ & n.d. & n.d. & {$[202]$} \\
\hline SNAP29 & R85X & - & ++ & n.d. & $=$ & $=$ & $=$ & $=$ & n.d. & n.d. & [203] \\
\hline SNAP29 & T130fsX17 & - & ++ & n.d. & $=$ & $=$ & $=$ & $=$ & n.d. & n.d. & [204] \\
\hline SNAP29 & P10fsX42 & - & ++ & n.d. & $=$ & $=$ & $=$ & $=$ & n.d. & n.d. & [204] \\
\hline SNAP29 & R90C & - & ++ & n.d. & $=$ & $=$ & $=$ & $=$ & n.d. & n.d. & [204] \\
\hline SNAP29 & E89K & - & ++ & n.d. & $=$ & $=$ & $=$ & $=$ & n.d. & n.d. & {$[204,205]$} \\
\hline SNAP29 & V75fsX28 & - & +++ & $=$ & $=$ & $=$ & $=$ & $=$ & $=$ & $?$ & [206] \\
\hline SNAP29 & S163fsX5 & - & ++ & n.d. & $=$ & $=$ & $=$ & $=$ & n.d. & n.d. & [207] \\
\hline GOSR2 & G144W & - & ++ & n.d. & n.d. & n.d. & n.d. & n.d. & n.d. & n.d. & {$[209,210]$} \\
\hline GOSR2 & K164del & - & + & n.d. & n.d. & n.d. & n.d. & n.d. & n.d. & n.d. & [209] \\
\hline
\end{tabular}

${ }^{a} \mathrm{X}$, confirmed congenital disorder of glycosylation; -, unconfirmed congenital disorder of glycosylation. ${ }^{\mathrm{b}}$ Severity of clinical symptoms. +, mild symptoms;,++ moderate symptoms;,+++

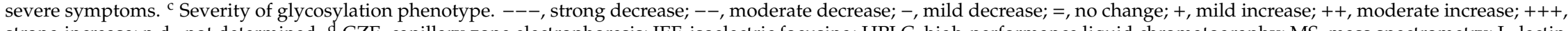
strong increase; n.d., not determined. ${ }^{\mathrm{d}} \mathrm{CZE}$, capillary zone electrophoresis; IEF, isoelectric focusing; HPLC, high-performance liquid chromatography; MS, mass spectrometry; L, lectin staining. ${ }^{1}$ New ATG start codon upstream of first exon, causing a frameshift and premature stop codon at c.26-28. ${ }^{2}$ Cryptic splice donor site activation. ${ }^{3}$ Intronic splice donor site; causes S793F in ITGB5. ${ }^{4}$ Intronic splice site. 
Interestingly, except for Stx5-CDG, all described CDGs in trafficking proteins primarily demonstrate defects in late glycan modifications such as galactosylation and sialylation (Table 1). Only in Stx5-CDG, the accumulation of an early-stage high mannose glycan is observed. Why could defects in early glycosylation steps be underrepresented? We can consider several hypotheses. First, correct glycosylation is of absolute importance for development [2,5], and despite the redundancy in glycosylation enzymes, defects affecting early glycosylation reactions might not be conducive to further development. Therefore, potential pathogenic mutations might remain undetected as they are non-viable. Second, as disorders of glycosylation are mostly a secondary effect of trafficking defects, glycosylation disorders might go undiagnosed as they simply have not been screened for in potential cases such as for GOSR2 mutations [209,210]. Last, early glycosylation defects might go undiagnosed because common biochemical techniques to measure glycosylation in a clinical setting, such as isoelectric focusing of transferrin and apolipoprotein CIII [227], mostly interrogate late glycosylation reactions such as sialylation. Modern advances in clinical diagnostics have added mass spectrometry of intact transferrin [72] and glycomics on total plasma N-glycans [155]. These two approaches have enabled measuring all $\mathrm{N}$-glycan structures on circulating serum proteins, thereby giving a more complete view of the glycosylation defects. This allows clinicians and scientists to identify more complex glycosylation disorders, including those in trafficking factors. Future advances to glycosylation screening might include measuring the glycome of all different tissues in the human body or measuring site-specific glycosylation on a large array of proteins. Understanding trafficking and glycosylation in different cellular contexts will ultimately further our knowledge of glycobiology and eventually increase therapeutic options for patients suffering from CDGs. A subcellular understanding of CDG can pave the road for targeted therapies through, for instance, gene replacement of affected genes or the development of small molecules to modulate ER-to-Golgi and intra-Golgi transport.

Funding: G.v.d.B. is funded by a Young Investigator Grant from the Human Frontier Science Program (HFSP; RGY0080/2018) and a Vidi grant from the Netherlands Organisation for Scientific Research (NWO-ALW VIDI 864.14.001). G.v.d.B has received funding from the European Research Council (ERC) under the European Union's Horizon 2020 research and innovation program (Grant Agreement No. 862137). D.J.L. is funded by a Vidi grant (ZONMW VIDI 917.13.359), a ZONMW Medium Investment Grant (40-00506-98-9001) from the Netherlands Organisation for Scientific Research, and Erare grants EUROCDG2 and Euroglycanomics.

Conflicts of Interest: The authors declare no conflict of interest.

\section{References}

1. Dennis, J.W.; Lau, K.S.; Demetriou, M.; Nabi, I.R. Adaptive Regulation at the Cell Surface by N-Glycosylation. Traffic 2009, 10, 1569-1578. [CrossRef]

2. Haltiwanger, R.S.; Lowe, J.B. Role of Glycosylation in Development. Annu. Rev. Biochem. 2004, 73, 491-537. [CrossRef]

3. Hoseki, J.; Ushioda, R.; Nagata, K. Mechanism and components of endoplasmic reticulum-associated degradation. J. Biochem. 2010, 147, 19-25. [CrossRef]

4. Kollmann, K.; Pohl, S.; Marschner, K.; Encarnação, M.; Sakwa, I.; Tiede, S.; Poorthuis, B.J.; Lübke, T.; Müller-Loennies, S.; Storch, S.; et al. Mannose phosphorylation in health and disease. Eur. J. Cell Biol. 2010, 89, 117-123. [CrossRef]

5. Moremen, K.W.; Tiemeyer, M.; Nairn, A.V. Vertebrate protein glycosylation: Diversity, synthesis and function. Nat. Rev. Mol. Cell Biol. 2012, 13, 448-462. [CrossRef]

6. Rothman, J.E.; Fine, R.E. Coated vesicles transport newly synthesized membrane glycoproteins from endoplasmic reticulum to plasma membrane in two successive stages. Proc. Natl. Acad. Sci. USA 1980, 77, 780-784. [CrossRef]

7. Varki, A. Biological roles of oligosaccharides: All of the theories are correct. Glycobiology 1993, 3, 97-130. [CrossRef] [PubMed]

8. Cummings, R.D. The repertoire of glycan determinants in the human glycome. Mol. BioSyst. 2009, 5, 1087-1104. [CrossRef] 
9. Joshi, H.J.; Hansen, L.; Narimatsu, Y.; Freeze, H.H.; Henrissat, B.; Bennett, E.; Wandall, H.H.; Clausen, H.; Schjoldager, K.T. Glycosyltransferase genes that cause monogenic congenital disorders of glycosylation are distinct from glycosyltransferase genes associated with complex diseases. Glycobiology 2018, 28, 284-294. [CrossRef]

10. Nairn, A.; Moremen, K. Handbook of Glycomics; Academic Press: Cambridge, MA, USA, 2009.

11. Nairn, A.V.; York, W.S.; Harris, K.; Hall, E.M.; Pierce, J.M.; Moremen, K.W. Regulation of Glycan Structures in Animal Tissues TRANSCRIPT PROFILING OF GLYCAN-RELATED GENES. J. Biol. Chem. 2008, 283, 17298-17313. [CrossRef]

12. Narimatsu, Y.; Joshi, H.J.; Nason, R.; Coillie, J.V.; Karlsson, R.; Sun, L.; Ye, Z.; Chen, Y.-H.; Schjoldager, K.T.; Steentoft, C.; et al. An Atlas of Human Glycosylation Pathways Enables Display of the Human Glycome by Gene Engineered Cells. Mol. Cell 2019, 75, 394-407.e5. [CrossRef] [PubMed]

13. Lombard, V.; Golaconda Ramulu, H.; Drula, E.; Coutinho, P.M.; Henrissat, B. The carbohydrate-active enzymes database (CAZy) in 2013. Nucleic Acids Res. 2014, 42, D490-D495. [CrossRef] [PubMed]

14. Riemersma, M.; Froese, D.S.; van Tol, W.; Engelke, U.F.; Kopec, J.; van Scherpenzeel, M.; Ashikov, A.; Krojer, T.; von Delft, F.; Tessari, M.; et al. Human ISPD Is a Cytidyltransferase Required for Dystroglycan O-Mannosylation. Chem. Biol. 2015, 22, 1643-1652. [CrossRef] [PubMed]

15. Kornfeld, R.; Kornfeld, S. Assembly of asparagine-linked oligosaccharides. Annu. Rev. Biochem. 1985, 54, 631-664. [CrossRef]

16. Lizak, C.; Gerber, S.; Numao, S.; Aebi, M.; Locher, K.P. X-ray structure of a bacterial oligosaccharyltransferase. Nature 2011, 474, 350-355. [CrossRef]

17. Ruiz-Canada, C.; Kelleher, D.J.; Gilmore, R. Cotranslational and Posttranslational N-Glycosylation of Polypeptides by Distinct Mammalian OST Isoforms. Cell 2009, 136, 272-283. [CrossRef]

18. Kelleher, D.J.; Gilmore, R. An evolving view of the eukaryotic oligosaccharyltransferase. Glycobiology 2006, 16, 47R-62R. [CrossRef]

19. Schreiner, R.; Schnabel, E.; Wieland, F. Novel N-glycosylation in eukaryotes: Laminin contains the linkage unit beta-glucosylasparagine. J. Cell Biol. 1994, 124, 1071-1081. [CrossRef]

20. Valliere-Douglass, J.F.; Eakin, C.M.; Wallace, A.; Ketchem, R.R.; Wang, W.; Treuheit, M.J.; Balland, A. Glutamine-linked and Non-consensus Asparagine-linked Oligosaccharides Present in Human Recombinant Antibodies Define Novel Protein Glycosylation Motifs. J. Biol. Chem. 2010, 285, 16012-16022. [CrossRef]

21. Zielinska, D.F.; Gnad, F.; Wiśniewski, J.R.; Mann, M. Precision Mapping of an In Vivo N-Glycoproteome Reveals Rigid Topological and Sequence Constraints. Cell 2010, 141, 897-907. [CrossRef]

22. Helenius, A.; Aebi, M. Roles of N-Linked Glycans in the Endoplasmic Reticulum. Annu. Rev. Biochem. 2004, 73, 1019-1049. [CrossRef]

23. Lederkremer, G.Z. Glycoprotein folding, quality control and ER-associated degradation. Curr. Opin. Struct. Biol. 2009, 19, 515-523. [CrossRef] [PubMed]

24. Appenzeller, C.; Andersson, H.; Kappeler, F.; Hauri, H.-P. The lectin ERGIC-53 is a cargo transport receptor for glycoproteins. Nat. Cell Biol. 1999, 1, 330-334. [CrossRef] [PubMed]

25. Appenzeller-Herzog, C.; Roche, A.-C.; Nufer, O.; Hauri, H.-P. pH-induced conversion of the transport lectin ERGIC-53 triggers glycoprotein release. J. Biol. Chem. 2004, 279, 12943-12950. [CrossRef] [PubMed]

26. Kamiya, Y.; Kamiya, D.; Yamamoto, K.; Nyfeler, B.; Hauri, H.-P.; Kato, K. Molecular Basis of Sugar Recognition by the Human L-type Lectins ERGIC-53, VIPL, and VIP36. J. Biol. Chem. 2008, 283, 1857-1861. [CrossRef]

27. Cottam, N.P.; Ungar, D. Retrograde vesicle transport in the Golgi. Protoplasma 2012, 249, 943-955. [CrossRef] [PubMed]

28. Papanikou, E.; Glick, B.S. The yeast Golgi apparatus: Insights and mysteries. FEBS Lett. 2009, 583, $3746-3751$. [CrossRef]

29. Jackson, C.L. Mechanisms of transport through the Golgi complex. J. Cell Sci. 2009, 122, 443-452. [CrossRef]

30. Rowe, T.; Dascher, C.; Bannykh, S.; Plutner, H.; Balch, W.E. Role of vesicle-associated syntaxin 5 in the assembly of pre-Golgi intermediates. Science 1998, 279, 696-700. [CrossRef]

31. Appenzeller-Herzog, C.; Hauri, H.-P. The ER-Golgi intermediate compartment (ERGIC): In search of its identity and function. J. Cell Sci. 2006, 119, 2173 LP-2183 LP. [CrossRef]

32. Dejgaard, S.Y.; Murshid, A.; Dee, K.M.; Presley, J.F. Confocal microscopy-based linescan methodologies for intra-Golgi localization of proteins. J. Histochem. Cytochem. 2007, 55, 709-719. [CrossRef] [PubMed] 
33. Freeze, H.H.; Ng, B.G. Golgi glycosylation and human inherited diseases. Cold Spring Harb. Perspect. Biol. 2011, 3, a005371. [CrossRef] [PubMed]

34. Rabouille, C.; Hui, N.; Hunte, F.; Kieckbusch, R.; Berger, E.G.; Warren, G.; Nilsson, T. Mapping the distribution of Golgi enzymes involved in the construction of complex oligosaccharides. J. Cell. Sci. 1995, 108, 1617-1627. [PubMed]

35. Stanley, P. Golgi Glycosylation. Cold Spring Harb. Perspect. Biol. 2011, 3, a005199. [CrossRef] [PubMed]

36. Mogelsvang, S.; Marsh, B.J.; Ladinsky, M.S.; Howell, K.E. Predicting Function from Structure: 3D Structure Studies of the Mammalian Golgi Complex. Traffic 2004, 5, 338-345. [CrossRef]

37. Nilsson, T.; Pypaert, M.; Hoe, M.H.; Slusarewicz, P.; Berger, E.G.; Warren, G. Overlapping distribution of two glycosyltransferases in the Golgi apparatus of HeLa cells. J. Cell Biol. 1993, 120, 5-13. [CrossRef]

38. Ripoche, J.; Link, B.; Yucel, J.K.; Tokuyasu, K.; Malhotra, V. Location of Golgi membranes with reference to dividing nuclei in syncytial Drosophila embryos. Proc. Natl. Acad. Sci. USA 1994, 91, 1878-1882. [CrossRef]

39. Velasco, A.; Hendricks, L.; Moremen, K.W.; Tulsiani, D.R.; Touster, O.; Farquhar, M.G. Cell type-dependent variations in the subcellular distribution of alpha-mannosidase I and II. J. Cell Biol. 1993, 122, 39-51. [CrossRef]

40. Forgac, M. Vacuolar ATPases: Rotary proton pumps in physiology and pathophysiology. Nat. Rev. Mol. Cell Biol. 2007, 8, 917. [CrossRef]

41. Nishi, T.; Forgac, M. The vacuolar (H+)-ATPases-nature's most versatile proton pumps. Nat. Rev. Mol. Cell Biol. 2002, 3, 94-103. [CrossRef]

42. Kawasaki-Nishi, S.; Bowers, K.; Nishi, T.; Forgac, M.; Stevens, T.H. The Amino-terminal Domain of the Vacuolar Proton-translocating ATPase a Subunit Controls Targeting and in Vivo Dissociation, and the Carboxyl-terminal Domain Affects Coupling of Proton Transport and ATP Hydrolysis. J. Biol. Chem. 2001, 276, 47411-47420. [CrossRef] [PubMed]

43. Kawasaki-Nishi, S.; Nishi, T.; Forgac, M. Yeast V-ATPase complexes containing different isoforms of the 100-kDa a-subunit differ in coupling efficiency and in vivo dissociation. J. Biol. Chem. 2001, 276, 17941-17948. [CrossRef] [PubMed]

44. Manolson, M.F.; Wu, B.; Proteau, D.; Taillon, B.E.; Roberts, B.T.; Hoyt, M.A.; Jones, E.W. STV1 gene encodes functional homologue of 95-kDa yeast vacuolar H(+)-ATPase subunit Vph1p. J. Biol. Chem. 1994, 269, 14064-14074.

45. Sun-Wada, G.-H.; Tabata, H.; Kawamura, N.; Aoyama, M.; Wada, Y. Direct recruitment of H+-ATPase from lysosomes for phagosomal acidification. J. Cell Sci. 2009, 122, 2504-2513. [CrossRef]

46. Toyomura, T.; Murata, Y.; Yamamoto, A.; Oka, T.; Sun-Wada, G.-H.; Wada, Y.; Futai, M. From Lysosomes to the Plasma Membrane Localization Of Vacuolar Type H+-ATPase With The A3 Isoform During Osteoclast Differentiation. J. Biol. Chem. 2003, 278, 22023-22030. [CrossRef]

47. Saw, N.M.N.; Kang, S.-Y.A.; Parsaud, L.; Han, G.A.; Jiang, T.; Grzegorczyk, K.; Surkont, M.; Sun-Wada, G.-H.; Wada, Y.; Li, L.; et al. Vacuolar H+-ATPase subunits Voa1 and Voa2 cooperatively regulate secretory vesicle acidification, transmitter uptake, and storage. MBoC 2011, 22, 3394-3409. [CrossRef]

48. Kornak, U.; Reynders, E.; Dimopoulou, A.; van Reeuwijk, J.; Fischer, B.; Rajab, A.; Budde, B.; Nürnberg, P.; Foulquier, F.; Lefeber, D.; et al. Impaired glycosylation and cutis laxa caused by mutations in the vesicular $\mathrm{H}$ +-ATPase subunit ATP6V0A2. Nat. Genet. 2008, 40, 32-34. [CrossRef]

49. Pietrement, C.; Sun-Wada, G.-H.; Da Silva, N.; McKee, M.; Marshansky, V.; Brown, D.; Futai, M.; Breton, S. Distinct Expression Patterns of Different Subunit Isoforms of the V-ATPase in the Rat Epididymis. Biol. Reprod. 2006, 74, 185-194. [CrossRef]

50. Hurtado-Lorenzo, A.; Skinner, M.; Annan, J.E.; Futai, M.; Sun-Wada, G.-H.; Bourgoin, S.; Casanova, J.; Wildeman, A.; Bechoua, S.; Ausiello, D.A.; et al. V-ATPase interacts with ARNO and Arf6 in early endosomes and regulates the protein degradative pathway. Nat. Cell Biol. 2006, 8, 124-136. [CrossRef]

51. Casey, J.R.; Grinstein, S.; Orlowski, J. Sensors and regulators of intracellular pH. Nat. Rev. Mol. Cell Biol. 2010, 11, 50-61. [CrossRef]

52. Gawlitzek, M.; Ryll, T.; Lofgren, J.; Sliwkowski, M.B. Ammonium alters N-glycan structures of recombinant TNFR-IgG: Degradative versus biosynthetic mechanisms. Biotechnol. Bioeng. 2000, 68, 637-646. [CrossRef]

53. Fisher, P.; Ungar, D. Bridging the Gap between Glycosylation and Vesicle Traffic. Front. Cell Dev. Biol. $2016,4$. [CrossRef] 
54. Rivinoja, A.; Hassinen, A.; Kokkonen, N.; Kauppila, A.; Kellokumpu, S. Elevated Golgi pH impairs terminal $\mathrm{N}$-glycosylation by inducing mislocalization of Golgi glycosyltransferases. J. Cell. Physiol. 2009, 220, 144-154. [CrossRef]

55. Maeda, Y.; Kinoshita, T. Chapter Twenty-Three-The Acidic Environment of the Golgi Is Critical for Glycosylation and Transport. In Methods in Enzymology; Glycobiology; Fukuda, M., Ed.; Academic Press: Cambridge, MA, USA, 2010; Volume 480, pp. 495-510.

56. Glick, B.S.; Nakano, A. Membrane Traffic Within the Golgi Apparatus. Ann. Rev. Cell Dev. Biol. 2009, 25, 113-132. [CrossRef]

57. Muschalik, N.; Munro, S. Golgins. Curr. Biol. 2018, 28, R374-R376. [CrossRef]

58. Wong, M.; Munro, S. The specificity of vesicle traffic to the Golgi is encoded in the golgin coiled-coil proteins. Science 2014, 346. [CrossRef] [PubMed]

59. Wong, M.; Gillingham, A.K.; Munro, S. The golgin coiled-coil proteins capture different types of transport carriers via distinct N-terminal motifs. BMC Biol. 2017, 15, 3. [CrossRef] [PubMed]

60. Drin, G.; Morello, V.; Casella, J.-F.; Gounon, P.; Antonny, B. Asymmetric Tethering of Flat and Curved Lipid Membranes by a Golgin. Science 2008, 320, 670-673. [CrossRef]

61. Fridmann-Sirkis, Y.; Siniossoglou, S.; Pelham, H.R. TMF is a golgin that binds Rab6 and influences Golgi morphology. BMC Cell Biol. 2004, 5, 18. [CrossRef]

62. Setty, S.R.G.; Shin, M.E.; Yoshino, A.; Marks, M.S.; Burd, C.G. Golgi Recruitment of GRIP Domain Proteins by Arf-like GTPase 1 Is Regulated by Arf-like GTPase 3. Curr. Biol. 2003, 13, 401-404. [CrossRef]

63. Kelly, E.E.; Giordano, F.; Horgan, C.P.; Jollivet, F.; Raposo, G.; McCaffrey, M.W. Rab30 is required for the morphological integrity of the Golgi apparatus. Biol. Cell 2012, 104, 84-101. [CrossRef]

64. Miserey-Lenkei, S.; Chalancon, G.; Bardin, S.; Formstecher, E.; Goud, B.; Echard, A. Rab and actomyosin-dependent fission of transport vesicles at the Golgi complex. Nat. Cell Biol. 2010, 12, 645-654. [CrossRef]

65. Hayes, G.L.; Brown, F.C.; Haas, A.K.; Nottingham, R.M.; Barr, F.A.; Pfeffer, S.R. Multiple Rab GTPase Binding Sites in GCC185 Suggest a Model for Vesicle Tethering at the Trans-Golgi. Mol. Biol. Cell 2009, 20, $209-217$. [CrossRef]

66. Zerial, M.; McBride, H.; Woodman, P.G.; Allan, V.J. Rab proteins as membrane organizers. Nat. Rev. Mol. Cell Biol. 2001, 2, 107-117. [CrossRef]

67. Wandinger-Ness, A.; Zerial, M. Rab Proteins and the Compartmentalization of the Endosomal System. Cold Spring Harb. Perspect. Biol. 2014, 6. [CrossRef] [PubMed]

68. Lees, J.A.; Yip, C.K.; Walz, T.; Hughson, F.M. Molecular organization of the COG vesicle tethering complex. Nat. Struct. Mol. Biol. 2010, 17, 1292-1297. [CrossRef]

69. Yu, I.-M.; Hughson, F.M. Tethering Factors as Organizers of Intracellular Vesicular Traffic. Annu. Rev. Cell Dev. Biol. 2010, 26, 137-156. [CrossRef]

70. Freeze, H.H. Genetic defects in the human glycome. Nat. Rev. Genet. 2006, 7, 537-551. [CrossRef]

71. Freeze,H.H.; Chong, J.X.; Bamshad, M.J.; Ng, B.G. Solving Glycosylation Disorders: Fundamental Approaches Reveal Complicated Pathways. Am. J. Hum. Genet. 2014, 94, 161-175. [CrossRef]

72. Van Scherpenzeel, M.; Steenbergen, G.; Morava, E.; Wevers, R.A.; Lefeber, D.J. High-resolution mass spectrometry glycoprofiling of intact transferrin for diagnosis and subtype identification in the congenital disorders of glycosylation. Trans. Res. 2015, 166, 639-649.e1. [CrossRef]

73. Morelle, W.; Michalski, J.-C. Analysis of protein glycosylation by mass spectrometry. Nat. Protoc. 2007, 2, 1585-1602. [CrossRef] [PubMed]

74. De Ligt, J.; Willemsen, M.H.; van Bon, B.W.M.; Kleefstra, T.; Yntema, H.G.; Kroes, T.; Vulto-van Silfhout, A.T.; Koolen, D.A.; de Vries, P.; Gilissen, C.; et al. Diagnostic Exome Sequencing in Persons with Severe Intellectual Disability. N. Engl. J. Med. 2012, 367, 1921-1929. [CrossRef]

75. Gilissen, C.; Hehir-Kwa, J.Y.; Thung, D.T.; van de Vorst, M.; van Bon, B.W.M.; Willemsen, M.H.; Kwint, M.; Janssen, I.M.; Hoischen, A.; Schenck, A.; et al. Genome sequencing identifies major causes of severe intellectual disability. Nature 2014, 511, 344-347. [CrossRef] [PubMed]

76. Galea, G.; Bexiga, M.G.; Panarella, A.; O’Neill, E.D.; Simpson, J.C. A high-content screening microscopy approach to dissect the role of Rab proteins in Golgi-to-ER retrograde trafficking. J. Cell Sci. 2015, 128, 2339-2349. [CrossRef] 
77. Axelsson, M.A.B.; Karlsson, N.G.; Steel, D.M.; Ouwendijk, J.; Nilsson, T.; Hansson, G.C. Neutralization of $\mathrm{pH}$ in the Golgi apparatus causes redistribution of glycosyltransferases and changes in the O-glycosylation of mucins. Glycobiology 2001, 11, 633-644. [CrossRef] [PubMed]

78. Ben-Tekaya, H.; Miura, K.; Pepperkok, R.; Hauri, H.-P. Live imaging of bidirectional traffic from the ERGIC. J. Cell Sci. 2005, 118, 357-367. [CrossRef]

79. Davis-Kaplan, S.R.; Compton, M.A.; Flannery, A.R.; Ward, D.M.; Kaplan, J.; Stevens, T.H.; Graham, L.A. PKR1 encodes an assembly factor for the yeast V-type ATPase. J. Biol. Chem. 2006, 281, 32025-32035. [CrossRef]

80. Malkus, P.; Graham, L.A.; Stevens, T.H.; Schekman, R. Role of Vma21p in assembly and transport of the yeast vacuolar ATPase. Mol. Biol. Cell 2004, 15, 5075-5091. [CrossRef]

81. Esmail, S.; Yao, Y.; Kartner, N.; Li, J.; Reithmeier, R.A.F.; Manolson, M.F. N-Linked Glycosylation Is Required for Vacuolar H+ -ATPase (V-ATPase) a4 Subunit Stability, Assembly, and Cell Surface Expression. J. Cell. Biochem. 2016, 117, 2757-2768. [CrossRef]

82. Esmail, S.; Kartner, N.; Yao, Y.; Kim, J.W.; Reithmeier, R.A.F.; Manolson, M.F. N-linked glycosylation of a subunit isoforms is critical for vertebrate vacuolar H+-ATPase (V-ATPase) biosynthesis. J. Cell. Biochem. 2017, 119, 861-875. [CrossRef]

83. Graham, L.A.; Flannery, A.R.; Stevens, T.H. Structure and assembly of the yeast V-ATPase. J. Bioenerg. Biomembr. 2003, 35, 301-312. [CrossRef] [PubMed]

84. Feng, H.; Cheng, T.; Pavlos, N.J.; Yip, K.H.M.; Carrello, A.; Seeber, R.; Eidne, K.; Zheng, M.H.; Xu, J. Cytoplasmic Terminus of Vacuolar Type Proton Pump Accessory Subunit Ac45 Is Required for Proper Interaction with V0 Domain Subunits and Efficient Osteoclastic Bone Resorption. J. Biol. Chem. 2008, 283, 13194-13204. [CrossRef] [PubMed]

85. Hodi, F.S.; Schmollinger, J.C.; Soiffer, R.J.; Salgia, R.; Lynch, T.; Ritz, J.; Alyea, E.P.; Yang, J.; Neuberg, D.; Mihm, M.; et al. ATP6S1 elicits potent humoral responses associated with immune-mediated tumor destruction. Proc. Natl. Acad. Sci. USA 2002, 99, 6919-6924. [CrossRef]

86. Holthuis, J.C.M.; Jansen, E.J.R.; Schoonderwoert, V.T.G.; Burbach, J.P.H.; Martens, G.J.M. Biosynthesis of the vacuolar H+-ATPase accessory subunit Ac45 in Xenopus pituitary. Eur. J. Biochem. 1999, 262, 484-491. [CrossRef]

87. Supek, F.; Supekova, L.; Mandiyan, S.; Pan, Y.C.; Nelson, H.; Nelson, N. A novel accessory subunit for vacuolar $\mathrm{H}(+)$-ATPase from chromaffin granules. J. Biol. Chem. 1994, 269, 24102-24106.

88. Jansen, E.J.R.; Scheenen, W.J.J.M.; Hafmans, T.G.M.; Martens, G.J.M. Accessory subunit Ac45 controls the V-ATPase in the regulated secretory pathway. Biochim. Biophys. Acta 2008, 1783, 2301-2310. [CrossRef]

89. Jansen, E.J.R.; Hafmans, T.G.M.; Martens, G.J.M. V-ATPase-Mediated Granular Acidification Is Regulated by the V-ATPase Accessory Subunit Ac45 in POMC-Producing Cells. Mol. Biol Cell 2010, 21, 3330-3339. [CrossRef]

90. Qin, A.; Cheng, T.S.; Lin, Z.; Pavlos, N.J.; Jiang, Q.; Xu, J.; Dai, K.R.; Zheng, M.H. Versatile Roles of V-ATPases Accessory Subunit Ac45 in Osteoclast Formation and Function. PLoS ONE 2011, 6, e27155. [CrossRef]

91. Yang, D.-Q.; Feng, S.; Chen, W.; Zhao, H.; Paulson, C.; Li, Y.-P. V-ATPase subunit ATP6AP1 (Ac45) regulates osteoclast differentiation, extracellular acidification, lysosomal trafficking, and protease exocytosis in osteoclast-mediated bone resorption. J. Bone Miner. Res. 2012, 27, 1695-1707. [CrossRef]

92. Jansen, E.J.R.; Timal, S.; Ryan, M.; Ashikov, A.; van Scherpenzeel, M.; Graham, L.A.; Mandel, H.; Hoischen, A.; Iancu, T.C.; Raymond, K.; et al. ATP6AP1 deficiency causes an immunodeficiency with hepatopathy, cognitive impairment and abnormal protein glycosylation. Nat. Commun. 2016, 7, 11600. [CrossRef]

93. Rujano, M.A.; Cannata Serio, M.; Panasyuk, G.; Péanne, R.; Reunert, J.; Rymen, D.; Hauser, V.; Park, J.H.; Freisinger, P.; Souche, E.; et al. Mutations in the X-linked ATP6AP2 cause a glycosylation disorder with autophagic defects. J. Exp. Med. 2017, 214, 3707-3729. [CrossRef]

94. Kinouchi, K.; Ichihara, A.; Sano, M.; Sun-Wada, G.-H.; Wada, Y.; Ochi, H.; Fukuda, T.; Bokuda, K.; Kurosawa, H.; Yoshida, N.; et al. The Role of Individual Domains and the Significance of Shedding of ATP6AP2/(pro)renin Receptor in Vacuolar H+-ATPase Biogenesis. PLoS ONE 2013, 8, e78603. [CrossRef]

95. Kenichiro, K.; Atsuhiro, I.; Motoaki, S.; Ge-Hong, S.-W.; Yoh, W.; Asako, K.-M.; Kanako, B.; Tatsuya, N.; Yoichi, O.; Mariyo, S.; et al. The (Pro)renin Receptor/ATP6AP2 is Essential for Vacuolar H+-ATPase Assembly in Murine Cardiomyocytes. Circ. Res. 2010, 107, 30-34. [CrossRef] 
96. Kissing, S.; Rudnik, S.; Damme, M.; Lüllmann-Rauch, R.; Ichihara, A.; Kornak, U.; Eskelinen, E.-L.; Jabs, S.; Heeren, J.; Brabander, J.K.D.; et al. Disruption of the vacuolar-type H+-ATPase complex in liver causes MTORC1-independent accumulation of autophagic vacuoles and lysosomes. Autophagy 2017, 13, 670-685. [CrossRef]

97. Cannata Serio, M.; Graham, L.A.; Ashikov, A.; Larsen, L.E.; Raymond, K.; Timal, S.; Le Meur, G.; Ryan, M.; Czarnowska, E.; Jansen, J.C.; et al. Mutations in the V-ATPase assembly factor VMA21 cause a congenital disorder of glycosylation with autophagic liver disease. Hepatology 2020. [CrossRef]

98. Dingjan, I.; Linders, P.T.A.; Verboogen, D.R.J.; Revelo, N.H.; ter Beest, M.; van den Bogaart, G. Endosomal and Phagosomal SNAREs. Physiol. Rev. 2018, 98, 1465-1492. [CrossRef]

99. Linders, P.T.; van der Horst, C.; ter Beest, M.; van den Bogaart, G. Stx5-Mediated ER-Golgi Transport in Mammals and Yeast. Cells 2019, 8, 780. [CrossRef]

100. Welsh, L.M.; Tong, A.H.Y.; Boone, C.; Jensen, O.N.; Otte, S. Genetic and molecular interactions of the Erv41p-Erv46p complex involved in transport between the endoplasmic reticulum and Golgi complex. J. Cell Sci. 2006, 119, 4730-4740. [CrossRef]

101. Jansen, J.C.; Cirak, S.; van Scherpenzeel, M.; Timal, S.; Reunert, J.; Rust, S.; Pérez, B.; Vicogne, D.; Krawitz, P.; Wada, Y.; et al. CCDC115 Deficiency Causes a Disorder of Golgi Homeostasis with Abnormal Protein Glycosylation. Am. J. Hum. Genet. 2016, 98, 310-321. [CrossRef]

102. Jansen, J.C.; Timal, S.; van Scherpenzeel, M.; Michelakakis, H.; Vicogne, D.; Ashikov, A.; Moraitou, M.; Hoischen, A.; Huijben, K.; Steenbergen, G.; et al. TMEM199 Deficiency Is a Disorder of Golgi Homeostasis Characterized by Elevated Aminotransferases, Alkaline Phosphatase, and Cholesterol and Abnormal Glycosylation. Am. J. Hum. Genet. 2016, 98, 322-330. [CrossRef]

103. Graham, L.A.; Hill, K.J.; Stevens, T.H. Assembly of the Yeast Vacuolar H+-ATPase Occurs in the Endoplasmic Reticulum and Requires a Vma12p/Vma22p Assembly Complex. J. Cell Biol. 1998, 142, 39-49. [CrossRef] [PubMed]

104. Hill, K.J.; Stevens, T.H. Vma22p Is a Novel Endoplasmic Reticulum-associated Protein Required for Assembly of the Yeast Vacuolar H+-ATPase Complex. J. Biol. Chem. 1995, 270, 22329-22336. [CrossRef] [PubMed]

105. Jackson, D.D.; Stevens, T.H. VMA12 Encodes a Yeast Endoplasmic Reticulum Protein Required for Vacuolar H+-ATPase Assembly. J. Biol. Chem. 1997, 272, 25928-25934. [CrossRef] [PubMed]

106. Miles, A.L.; Burr, S.P.; Grice, G.L.; Nathan, J.A. The vacuolar-ATPase complex and assembly factors, TMEM199 and CCDC115, control HIF1 $\alpha$ prolyl hydroxylation by regulating cellular iron levels. eLife 2017, 6, e22693. [CrossRef]

107. Nishi, T.; Forgac, M. Molecular cloning and expression of three isoforms of the 100-kDa a subunit of the mouse vacuolar proton-translocating ATPase. J. Biol. Chem. 2000, 275, 6824-6830. [CrossRef]

108. Schulz, N.; Dave, M.H.; Stehberger, P.A.; Chau, T.C.; Wagner, C.A. Differential Localization of Vacuolar H+-ATPases Containing a1, a2, a3, or a4 (ATP6V0A1-4) Subunit Isoforms Along the Nephron. Cell. Physiol. Biochem. 2007, 20, 109-120. [CrossRef]

109. Toyomura, T.; Oka, T.; Yamaguchi, C.; Wada, Y.; Futai, M. Three Subunit a Isoforms of Mouse Vacuolar H+-ATPase Preferential Expression Of The A3 Isoform During Osteoclast Differentiation. J. Biol. Chem. 2000, 275, 8760-8765. [CrossRef]

110. Li, B.; Clohisey, S.M.; Chia, B.S.; Wang, B.; Cui, A.; Eisenhaure, T.; Schweitzer, L.D.; Hoover, P.; Parkinson, N.J.; Nachshon, A.; et al. Genome-wide CRISPR screen identifies host dependency factors for influenza A virus infection. Nat. Commun. 2020, 11. [CrossRef]

111. Foulquier, F.; Amyere, M.; Jaeken, J.; Zeevaert, R.; Schollen, E.; Race, V.; Bammens, R.; Morelle, W.; Rosnoblet, C.; Legrand, D.; et al. TMEM165 Deficiency Causes a Congenital Disorder of Glycosylation. Am. J. Hum. Genet. 2012, 91, 15-26. [CrossRef]

112. Potelle, S.; Morelle, W.; Dulary, E.; Duvet, S.; Vicogne, D.; Spriet, C.; Krzewinski-Recchi, M.-A.; Morsomme, P.; Jaeken, J.; Matthijs, G.; et al. Glycosylation abnormalities in Gdt1p/TMEM165 deficient cells result from a defect in Golgi manganese homeostasis. Hum. Mol. Genet. 2016, 25, 1489-1500. [CrossRef]

113. Park, J.H.; Hogrebe, M.; Grüneberg, M.; DuChesne, I.; von der Heiden, A.L.; Reunert, J.; Schlingmann, K.P.; Boycott, K.M.; Beaulieu, C.L.; Mhanni, A.A.; et al. SLC39A8 Deficiency: A Disorder of Manganese Transport and Glycosylation. Am. J. Hum. Genet. 2015, 97, 894-903. [CrossRef] [PubMed]

114. Powell, J.T.; Brew, K. Metal ion activation of galactosyltransferase. J. Biol. Chem. 1976, 251, 3645-3652. [PubMed] 
115. Witkos, T.M.; Lowe, M. The Golgin Family of Coiled-Coil Tethering Proteins. Front. Cell Dev. Biol. $2016,3,86$. [CrossRef] [PubMed]

116. Barr, F.A.; Puype, M.; Vandekerckhove, J.; Warren, G. GRASP65, a protein involved in the stacking of Golgi cisternae. Cell 1997, 91, 253-262. [CrossRef]

117. Smits, P.; Bolton, A.D.; Funari, V.; Hong, M.; Boyden, E.D.; Lu, L.; Manning, D.K.; Dwyer, N.D.; Moran, J.L.; Prysak, M.; et al. Lethal Skeletal Dysplasia in Mice and Humans Lacking the Golgin GMAP-210. N. Engl. J. Med. 2010, 362, 206-216. [CrossRef]

118. Roboti, P.; Sato, K.; Lowe, M. The golgin GMAP-210 is required for efficient membrane trafficking in the early secretory pathway. J. Cell. Sci. 2015, 128, 1595-1606. [CrossRef]

119. Sato, K.; Roboti, P.; Mironov, A.A.; Lowe, M. Coupling of vesicle tethering and Rab binding is required for in vivo functionality of the golgin GMAP-210. MBoC 2014, 26, 537-553. [CrossRef]

120. Wehrle, A.; Witkos, T.M.; Unger, S.; Schneider, J.; Follit, J.A.; Hermann, J.; Welting, T.; Fano, V.; Hietala, M.; Vatanavicharn, N.; et al. Hypomorphic mutations of TRIP11 cause odontochondrodysplasia. JCI Insight 2019, 4. [CrossRef]

121. Lan, Y.; Zhang, N.; Liu, H.; Xu, J.; Jiang, R. Golgb1 regulates protein glycosylation and is crucial for mammalian palate development. Development 2016, 143, 2344-2355. [CrossRef]

122. Satoh, A.; Hayashi-Nishino, M.; Shakuno, T.; Masuda, J.; Koreishi, M.; Murakami, R.; Nakamura, Y.; Nakamura, T.; Abe-Kanoh, N.; Honjo, Y.; et al. The Golgin Protein Giantin Regulates Interconnections Between Golgi Stacks. Front. Cell Dev. Biol. 2019, 7. [CrossRef]

123. Koreishi, M.; Gniadek, T.J.; Yu, S.; Masuda, J.; Honjo, Y.; Satoh, A. The Golgin Tether Giantin Regulates the Secretory Pathway by Controlling Stack Organization within Golgi Apparatus. PLoS ONE 2013, 8, e59821. [CrossRef] [PubMed]

124. Xiang, Y.; Zhang, X.; Nix, D.B.; Katoh, T.; Aoki, K.; Tiemeyer, M.; Wang, Y. Regulation of protein glycosylation and sorting by the Golgi matrix proteins GRASP55/65. Nat. Commun. 2013, 4, 1659. [CrossRef]

125. Witkos, T.M.; Chan, W.L.; Joensuu, M.; Rhiel, M.; Pallister, E.; Thomas-Oates, J.; Mould, A.P.; Mironov, A.A.; Biot, C.; Guerardel, Y.; et al. GORAB scaffolds COPI at the trans -Golgi for efficient enzyme recycling and correct protein glycosylation. Nat. Commun. 2019, 10, 1-18. [CrossRef]

126. Lowe, M. The Physiological Functions of the Golgin Vesicle Tethering Proteins. Front. Cell Dev. Biol. $2019,7$. [CrossRef]

127. Hennies, H.C.; Kornak, U.; Zhang, H.; Egerer, J.; Zhang, X.; Seifert, W.; Kühnisch, J.; Budde, B.; Nätebus, M.; Brancati, F.; et al. Gerodermia osteodysplastica is caused by mutations in SCYL1BP1, a Rab-6 interacting golgin. Nat. Genet. 2008, 40, 1410-1412. [CrossRef]

128. Chan, W.L.; Steiner, M.; Witkos, T.; Egerer, J.; Busse, B.; Mizumoto, S.; Pestka, J.M.; Zhang, H.; Hausser, I.; Khayal, L.A.; et al. Impaired proteoglycan glycosylation, elevated TGF- $\beta$ signaling, and abnormal osteoblast differentiation as the basis for bone fragility in a mouse model for gerodermia osteodysplastica. PLoS Genet. 2018, 14, e1007242. [CrossRef] [PubMed]

129. Hunter, A.G.W.; Martsolf, J.T.; Baker, C.G.; Reed, M.H. Geroderma osteodysplastica. Hum. Genet. 1978, 40, 311-324. [CrossRef] [PubMed]

130. Lisker, R.; Hernández, A.; Martínez-Lavin, M.; Mutchinick, O.; Armas, C.; Reyes, P.; Robles-Gil, J.; Optiz, J.M. Gerodermia osteodysplastica hereditaria: Report of three affected brothers and literature review. Am. J. Med. Genet. 1979, 3, 389-395. [CrossRef]

131. Burman, J.L.; Bourbonniere, L.; Philie, J.; Stroh, T.; Dejgaard, S.Y.; Presley, J.F.; McPherson, P.S. Scyl1, mutated in a recessive form of spinocerebellar neurodegeneration, regulates COPI-mediated retrograde traffic. J. Biol. Chem. 2008, 283, 22774-22786. [CrossRef]

132. Lenz, D.; McClean, P.; Kansu, A.; Bonnen, P.E.; Ranucci, G.; Thiel, C.; Straub, B.K.; Harting, I.; Alhaddad, B.; Dimitrov, B.; et al. SCYL1 variants cause a syndrome with low $\gamma$-glutamyl-transferase cholestasis, acute liver failure, and neurodegeneration (CALFAN). Genet. Med. 2018, 20, 1255-1265. [CrossRef]

133. Schmidt, W.M.; Kraus, C.; Höger, H.; Hochmeister, S.; Oberndorfer, F.; Branka, M.; Bingemann, S.; Lassmann, H.; Müller, M.; Macedo-Souza, L.I.; et al. Mutation in the Scyl1 gene encoding amino-terminal kinase-like protein causes a recessive form of spinocerebellar neurodegeneration. EMBO Rep. 2007, 8, 691-697. [CrossRef] 
134. Schmidt, W.M.; Rutledge, S.L.; Schüle, R.; Mayerhofer, B.; Züchner, S.; Boltshauser, E.; Bittner, R.E. Disruptive SCYL1 Mutations Underlie a Syndrome Characterized by Recurrent Episodes of Liver Failure, Peripheral Neuropathy, Cerebellar Atrophy, and Ataxia. Am. J. Hum. Genet. 2015, 97, 855-861. [CrossRef]

135. Climer, L.K.; Dobretsov, M.; Lupashin, V. Defects in the COG complex and COG-related trafficking regulators affect neuronal Golgi function. Front. Neurosci. 2015, 9. [CrossRef]

136. Fukuda, M. Regulation of secretory vesicle traffic by Rab small GTPases. Cell. Mol. Life Sci. 2008, 65, 2801-2813. [CrossRef]

137. Oka, T.; Vasile, E.; Penman, M.; Novina, C.D.; Dykxhoorn, D.M.; Ungar, D.; Hughson, F.M.; Krieger, M. Genetic Analysis of the Subunit Organization and Function of the Conserved Oligomeric Golgi (COG) Complex Studies of COG5- and COG7-Deficient Mammalian Cells. J. Biol. Chem. 2005, 280, 32736-32745. [CrossRef]

138. Oka, T.; Ungar, D.; Hughson, F.M.; Krieger, M. The COG and COPI Complexes Interact to Control the Abundance of GEARs, a Subset of Golgi Integral Membrane Proteins. MBoC 2004, 15, 2423-2435. [CrossRef]

139. Witkos, T.M.; Lowe, M. Recognition and tethering of transport vesicles at the Golgi apparatus. Curr. Opin. Cell Biol. 2017, 47, 16-23. [CrossRef]

140. Blackburn, J.B.; D’Souza, Z.; Lupashin, V.V. Maintaining order: COG complex controls Golgi trafficking, processing, and sorting. FEBS Lett. 2019, 593, 2466-2487. [CrossRef]

141. Kudlyk, T.; Willett, R.; Pokrovskaya, I.D.; Lupashin, V. COG6 Interacts with a Subset of the Golgi SNAREs and Is Important for the Golgi Complex Integrity. Traffic 2013, 14, 194-204. [CrossRef]

142. Shestakova, A.; Suvorova, E.; Pavliv, O.; Khaidakova, G.; Lupashin, V. Interaction of the conserved oligomeric Golgi complex with t-SNARE Syntaxin5a/Sed5 enhances intra-Golgi SNARE complex stability. J. Cell Biol. 2007, 179, 1179-1192. [CrossRef]

143. Willett, R.; Kudlyk, T.; Pokrovskaya, I.; Schönherr, R.; Ungar, D.; Duden, R.; Lupashin, V. COG complexes form spatial landmarks for distinct SNARE complexes. Nat. Commun. 2013, 4, 1553. [CrossRef] [PubMed]

144. Smith, R.D.; Willett, R.; Kudlyk, T.; Pokrovskaya, I.; Paton, A.W.; Paton, J.C.; Lupashin, V.V. The COG Complex, Rab6 and COPI Define a Novel Golgi Retrograde Trafficking Pathway that is Exploited by SubAB Toxin. Traffic 2009, 10, 1502-1517. [CrossRef] [PubMed]

145. Willett, R.; Blackburn, J.B.; Climer, L.; Pokrovskaya, I.; Kudlyk, T.; Wang, W.; Lupashin, V. COG lobe B sub-complex engages v-SNARE GS15 and functions via regulated interaction with lobe A sub-complex. Sci. Rep. 2016, 6, 29139. [CrossRef] [PubMed]

146. Miller, V.J.; Ungar, D. Re'COG'nition at the Golgi. Traffic 2012, 13, 891-897. [CrossRef]

147. Shestakova, A.; Zolov, S.; Lupashin, V. COG Complex-Mediated Recycling of Golgi Glycosyltransferases is Essential for Normal Protein Glycosylation. Traffic 2006, 7, 191-204. [CrossRef]

148. Pokrovskaya, I.D.; Willett, R.; Smith, R.D.; Morelle, W.; Kudlyk, T.; Lupashin, V.V. Conserved oligomeric Golgi complex specifically regulates the maintenance of Golgi glycosylation machinery. Glycobiology 2011, 21, 1554-1569. [CrossRef]

149. Reynders, E.; Foulquier, F.; Annaert, W.; Matthijs, G. How Golgi glycosylation meets and needs trafficking: The case of the COG complex. Glycobiology 2011, 21, 853-863. [CrossRef]

150. Ong, Y.S.; Tran, T.H.T.; Gounko, N.V.; Hong, W. TMEM115 is an integral membrane protein of the Golgi complex involved in retrograde transport. J. Cell Sci. 2014, 127, 2825-2839. [CrossRef]

151. Climer, L.K.; Pokrovskaya, I.D.; Blackburn, J.B.; Lupashin, V.V. Membrane detachment is not essential for COG complex function. MBoC 2018, 29, 964-974. [CrossRef]

152. Kodera, H.; Ando, N.; Yuasa, I.; Wada, Y.; Tsurusaki, Y.; Nakashima, M.; Miyake, N.; Saitoh, S.; Matsumoto, N.; Saitsu, H. Mutations in COG2 encoding a subunit of the conserved oligomeric golgi complex cause a congenital disorder of glycosylation. Clin. Genet. 2015, 87, 455-460. [CrossRef]

153. Foulquier, F.; Vasile, E.; Schollen, E.; Callewaert, N.; Raemaekers, T.; Quelhas, D.; Jaeken, J.; Mills, P.; Winchester, B.; Krieger, M.; et al. Conserved oligomeric Golgi complex subunit 1 deficiency reveals a previously uncharacterized congenital disorder of glycosylation type II. Proc. Natl. Acad. Sci. USA 2006, 103, 3764-3769. [CrossRef] [PubMed]

154. Palmigiano, A.; Bua, R.O.; Barone, R.; Rymen, D.; Régal, L.; Deconinck, N.; Dionisi-Vici, C.; Fung, C.-W.; Garozzo, D.; Jaeken, J.; et al. MALDI-MS profiling of serum O-glycosylation and N-glycosylation in COG5-CDG. J. Mass Spectrom. 2017, 52, 372-377. [CrossRef] 
155. Abu Bakar, N.; Lefeber, D.J.; van Scherpenzeel, M. Clinical glycomics for the diagnosis of congenital disorders of glycosylation. J. Inherit. Metab. Dis. 2018, 41, 499-513. [CrossRef] [PubMed]

156. Foulquier, F. COG defects, birth and rise! Biochim. Biophys. Acta (BBA) Mol. Basis Dis. 2009, 1792, 896-902. [CrossRef] [PubMed]

157. Morava, E.; Zeevaert, R.; Korsch, E.; Huijben, K.; Wopereis, S.; Matthijs, G.; Keymolen, K.; Lefeber, D.J.; Meirleir, L.D.; Wevers, R.A. A common mutation in the COG7 gene with a consistent phenotype including microcephaly, adducted thumbs, growth retardation, VSD and episodes of hyperthermia. Eur. J. Hum. Genet. 2007, 15, 638-645. [CrossRef]

158. Ng, B.G.; Kranz, C.; Hagebeuk, E.E.O.; Duran, M.; Abeling, N.G.G.M.; Wuyts, B.; Ungar, D.; Lupashin, V.; Hartdorff, C.M.; Poll-The, B.T.; et al. Molecular and clinical characterization of a Moroccan Cog7 deficient patient. Mol. Genet. Metab. 2007, 91, 201-204. [CrossRef]

159. Kranz, C.; Ng, B.G.; Sun, L.; Sharma, V.; Eklund, E.A.; Miura, Y.; Ungar, D.; Lupashin, V.; Winkel, R.D.; Cipollo, J.F.; et al. COG8 deficiency causes new congenital disorder of glycosylation type IIh. Hum. Mol. Genet. 2007, 16, 731-741. [CrossRef]

160. Foulquier, F.; Ungar, D.; Reynders, E.; Zeevaert, R.; Mills, P.; García-Silva, M.T.; Briones, P.; Winchester, B.; Morelle, W.; Krieger, M.; et al. A new inborn error of glycosylation due to a Cog8 deficiency reveals a critical role for the Cog1-Cog8 interaction in COG complex formation. Hum. Mol. Genet. 2007, 16, 717-730. [CrossRef]

161. Zeevaert, R.; Foulquier, F.; Dimitrov, B.; Reynders, E.; Van Damme-Lombaerts, R.; Simeonov, E.; Annaert, W.; Matthijs, G.; Jaeken, J. Cerebrocostomandibular-like syndrome and a mutation in the conserved oligomeric Golgi complex, subunit 1. Hum. Mol. Genet. 2009, 18, 517-524. [CrossRef]

162. Ng, B.G.; Sharma, V.; Sun, L.; Loh, E.; Hong, W.; Tay, S.K.H.; Freeze, H.H. Identification of the first COG-CDG patient of Indian origin. Mol. Genet. Metab. 2011, 102, 364-367. [CrossRef]

163. Miura, Y.; Tay, S.K.H.; Aw, M.M.; Eklund, E.A.; Freeze, H.H. Clinical and Biochemical Characterization of a Patient with Congenital Disorder of Glycosylation (CDG) IIx. J. Pediatr. 2005, 147, 851-853. [CrossRef]

164. Reynders, E.; Foulquier, F.; Leão Teles, E.; Quelhas, D.; Morelle, W.; Rabouille, C.; Annaert, W.; Matthijs, G. Golgi function and dysfunction in the first COG4-deficient CDG type II patient. Hum. Mol. Genet. 2009, 18, 3244-3256. [CrossRef] [PubMed]

165. Ferreira, C.R.; Xia, Z.-J.; Clément, A.; Parry, D.A.; Davids, M.; Taylan, F.; Sharma, P.; Turgeon, C.T.; Blanco-Sánchez, B.; Ng, B.G.; et al. A Recurrent De Novo Heterozygous COG4 Substitution Leads to Saul-Wilson Syndrome, Disrupted Vesicular Trafficking, and Altered Proteoglycan Glycosylation. Am. J. Hum. Genet. 2018, 103, 553-567. [CrossRef] [PubMed]

166. Fung, C.W.; Matthijs, G.; Sturiale, L.; Garozzo, D.; Wong, K.Y.; Wong, R.; Wong, V.; Jaeken, J. COG5-CDG with a Mild Neurohepatic Presentation. JIMD Rep. 2012, 3, 67-70. [CrossRef] [PubMed]

167. Paesold-Burda, P.; Maag, C.; Troxler, H.; Foulquier, F.; Kleinert, P.; Schnabel, S.; Baumgartner, M.; Hennet, T. Deficiency in COG5 causes a moderate form of congenital disorders of glycosylation. Hum. Mol. Genet. 2009, 18, 4350-4356. [CrossRef] [PubMed]

168. Rymen, D.; Keldermans, L.; Race, V.; Régal, L.; Deconinck, N.; Dionisi-Vici, C.; Fung, C.-W.; Sturiale, L.; Rosnoblet, C.; Foulquier, F.; et al. COG5-CDG: Expanding the clinical spectrum. Orphanet J. Rare Dis. 2012, 7, 94. [CrossRef]

169. Lübbehusen, J.; Thiel, C.; Rind, N.; Ungar, D.; Prinsen, B.H.C.M.T.; de Koning, T.J.; van Hasselt, P.M.; Körner, C. Fatal outcome due to deficiency of subunit 6 of the conserved oligomeric Golgi complex leading to a new type of congenital disorders of glycosylation. Hum. Mol. Genet. 2010, 19, 3623-3633. [CrossRef]

170. Huybrechts, S.; De Laet, C.; Bontems, P.; Rooze, S.; Souayah, H.; Sznajer, Y.; Sturiale, L.; Garozzo, D.; Matthijs, G.; Ferster, A.; et al. Deficiency of Subunit 6 of the Conserved Oligomeric Golgi Complex (COG6-CDG): Second Patient, Different Phenotype. JIMD Rep. 2012, 4, 103-108. [CrossRef]

171. Shaheen, R.; Ansari, S.; Alshammari, M.J.; Alkhalidi, H.; Alrukban, H.; Eyaid, W.; Alkuraya, F.S. A novel syndrome of hypohidrosis and intellectual disability is linked to COG6 deficiency. J. Med. Genet. 2013, 50, 431-436. [CrossRef]

172. Rymen, D.; Winter, J.; Van Hasselt, P.M.; Jaeken, J.; Kasapkara, C.; Gokçay, G.; Haijes, H.; Goyens, P.; Tokatli, A.; Thiel, C.; et al. Key features and clinical variability of COG6-CDG. Mol. Genet. Metab. 2015, 116, 163-170. [CrossRef] 
173. Zeevaert, R.; Foulquier, F.; Cheillan, D.; Cloix, I.; Guffon, N.; Sturiale, L.; Garozzo, D.; Matthijs, G.; Jaeken, J. A new mutation in COG7 extends the spectrum of COG subunit deficiencies. Eur. J. Med. Genet. 2009, 52, 303-305. [CrossRef]

174. Spaapen, L.J.M.; Bakker, J.A.; van der Meer, S.B.; Sijstermans, H.J.; Steet, R.A.; Wevers, R.A.; Jaeken, J. Clinical and biochemical presentation of siblings with COG-7 deficiency, a lethal multiple O- and N-glycosylation disorder. J. Inherit. Metab. Dis. 2005, 28, 707. [CrossRef]

175. Wu, X.; Steet, R.A.; Bohorov, O.; Bakker, J.; Newell, J.; Krieger, M.; Spaapen, L.; Kornfeld, S.; Freeze, H.H. Mutation of the COG complex subunit gene COG7 causes a lethal congenital disorder. Nat. Med. 2004, 10, 518-523. [CrossRef]

176. Hong, W. SNAREs and traffic. Biochim. Biophys. Acta (BBA) Mol. Cell Res. 2005, 1744, 120-144. [CrossRef]

177. Jahn, R.; Scheller, R.H. SNAREs-Engines for membrane fusion. Nat. Rev. Mol. Cell Biol. 2006, 7, $631-643$. [CrossRef]

178. Xu, D.; Joglekar, A.P.; Williams, A.L.; Hay, J.C. Subunit structure of a mammalian ER/Golgi SNARE complex. J. Biol. Chem. 2000, 275, 39631-39639. [CrossRef]

179. Zhang, T.; Hong, W.; Rahimian, V.; Doege, C.A.; Paumet, F.; Eng, W.S.; Arango, N.; Parlati, F.; Ravazzola, M.; Orci, L.; et al. Ykt6 forms a SNARE complex with syntaxin 5, GS28, and Bet1 and participates in a late stage in endoplasmic reticulum-Golgi transport. J. Biol. Chem. 2001, 276, 27480-27487. [CrossRef]

180. Dascher, C.; Matteson, J.; Balch, W.E. Syntaxin 5 regulates endoplasmic reticulum to Golgi transport. J. Biol. Chem. 1994, 269, 29363-29366. [PubMed]

181. Hay, J.C.; Hirling, H.; Scheller, R.H. Mammalian vesicle trafficking proteins of the endoplasmic reticulum and Golgi apparatus. J. Biol. Chem. 1996, 271, 5671-5679. [CrossRef] [PubMed]

182. Hay, J.C.; Klumperman, J.; Oorschot, V.; Steegmaier, M.; Kuo, C.S.; Scheller, R.H. Localization, Dynamics, and Protein Interactions Reveal Distinct Roles for ER and Golgi SNAREs. J. Cell Biol. 1998, 141, 1489-1502. [CrossRef] [PubMed]

183. Paek, I.; Orci, L.; Ravazzola, M.; Erdjument-Bromage, H.; Amherdt, M.; Tempst, P.; Söllner, T.H.; Rothman, J.E. ERS-24, a Mammalian v-SNARE Implicated in Vesicle Traffic between the ER and the Golgi. J. Cell Biol. 1997, 137, 1017-1028. [CrossRef] [PubMed]

184. Zhang, T.; Wong, S.H.; Tang, B.L.; Xu, Y.; Peter, F.; Subramaniam, V.N.; Hong, W. The Mammalian Protein (rbet1) Homologous to Yeast Bet1p Is Primarily Associated with the Pre-Golgi Intermediate Compartment and Is Involved in Vesicular Transport from the Endoplasmic Reticulum to the Golgi Apparatus. J. Cell Biol. 1997, 139, 1157-1168. [CrossRef] [PubMed]

185. Adolf, F.; Rhiel, M.; Reckmann, I.; Wieland, F.T. Sec24C/D-isoform-specific sorting of the preassembled ER-Golgi Q-SNARE complex. Mol. Biol. Cell 2016, 27, 2697-2707. [CrossRef] [PubMed]

186. Malsam, J.; Söllner, T.H. Organization of SNAREs within the Golgi stack. Cold Spring Harb. Persp. Biol. 2011, 3, a005249. [CrossRef]

187. Burri, L.; Varlamov, O.; Doege, C.A.; Hofmann, K.; Beilharz, T.; Rothman, J.E.; Söllner, T.H.; Lithgow, T. A SNARE required for retrograde transport to the endoplasmic reticulum. Proc. Natl. Acad. Sci. USA 2003, 100, 9873-9877. [CrossRef]

188. Xu, Y.; Martin, S.; James, D.E.; Hong, W. GS15 Forms a SNARE Complex with Syntaxin 5, GS28, and Ykt6 and Is Implicated in Traffic in the Early Cisternae of the Golgi Apparatus. MBoC 2002, 13, 3493-3507. [CrossRef]

189. Volchuk, A.; Ravazzola, M.; Perrelet, A.; Eng, W.S.; Di Liberto, M.; Varlamov, O.; Fukasawa, M.; Engel, T.; Söllner, T.H.; Rothman, J.E.; et al. Countercurrent Distribution of Two Distinct SNARE Complexes Mediating Transport within the Golgi Stack. MBoC 2004, 15, 1506-1518. [CrossRef]

190. Tai, G.; Lu, L.; Wang, T.L.; Tang, B.L.; Goud, B.; Johannes, L.; Hong, W. Participation of the Syntaxin 5/Ykt6/GS28/GS15 SNARE Complex in Transport from the Early/Recycling Endosome to the Trans-Golgi Network. MBoC 2004, 15, 4011-4022. [CrossRef]

191. Linders, P.; Gerretsen, E.; Ashikov, A.; Vals, M.-A.; Revelo, N.H.; Arts, R.; Baerenfaenger, M.; Zijlstra, F.; Huijben, K.; Raymond, K.; et al. Congenital disorder of glycosylation caused by starting site-specific variant in syntaxin-5. MedRXiv 2004. [CrossRef]

192. Banfield, D.K.; Lewis, M.J.; Pelham, H.R.B. A SNARE-like protein required for traffic through the Golgi complex. Nature 1995, 375, 806-809. [CrossRef]

193. Parlati, F.; McNew, J.A.; Fukuda, R.; Miller, R.; Söllner, T.H.; Rothman, J.E. Topological restriction of SNARE-dependent membrane fusion. Nature 2000, 407, 194-198. [CrossRef] [PubMed] 
194. Parlati, F.; Varlamov, O.; Paz, K.; McNew, J.A.; Hurtado, D.; Söllner, T.H.; Rothman, J.E. Distinct SNARE complexes mediating membrane fusion in Golgi transport based on combinatorial specificity. Proc. Natl. Acad. Sci. USA 2002, 99, 5424-5429. [CrossRef]

195. Araç, D.; Dulubova, I.; Pei, J.; Huryeva, I.; Grishin, N.V.; Rizo, J. Three-dimensional Structure of the rSly1 N-terminal Domain Reveals a Conformational Change Induced by Binding to Syntaxin 5. J. Mol. Biol. 2005, 346, 589-601. [CrossRef]

196. Bracher, A.; Weissenhorn, W. Structural basis for the Golgi membrane recruitment of Sly1p by Sed5p. EMBO J. 2002, 21, 6114-6124. [CrossRef]

197. Peng, R.; Gallwitz, D. Sly1 protein bound to Golgi syntaxin Sed5p allows assembly and contributes to specificity of SNARE fusion complexes. J. Cell Biol. 2002, 157, 645-655. [CrossRef]

198. Yamaguchi, T.; Dulubova, I.; Min, S.-W.; Chen, X.; Rizo, J.; Südhof, T.C. Sly1 Binds to Golgi and ER Syntaxins via a Conserved N-Terminal Peptide Motif. Dev. Cell 2002, 2, 295-305. [CrossRef]

199. Hui, N.; Nakamura, N.; Sönnichsen, B.; Shima, D.T.; Nilsson, T.; Warren, G. An isoform of the Golgi t-SNARE, syntaxin 5, with an endoplasmic reticulum retrieval signal. Mol. Biol. Cell 1997, 8, 1777-1787. [CrossRef] [PubMed]

200. Morelli, E.; Ginefra, P.; Mastrodonato, V.; Beznoussenko, G.V.; Rusten, T.E.; Bilder, D.; Stenmark, H.; Mironov, A.A.; Vaccari, T. Multiple functions of the SNARE protein SNAP29 in autophagy, endocytic, and exocytic trafficking during epithelial formation in Drosophila. Autophagy 2014, 10, 2251-2268. [CrossRef]

201. Hsu, T.; Coughlin, C.C.; Monaghan, K.G.; Fiala, E.; McKinstry, R.C.; Paciorkowski, A.R.; Shinawi, M. CEDNIK: Phenotypic and Molecular Characterization of an Additional Patient and Review of the Literature. Child Neurol. Open 2017. [CrossRef]

202. Llaci, L.; Ramsey, K.; Belnap, N.; Claasen, A.M.; Balak, C.D.; Szelinger, S.; Jepsen, W.M.; Siniard, A.L.; Richholt, R.; Izat, T.; et al. Compound heterozygous mutations in SNAP29 is associated with Pelizaeus-Merzbacher-like disorder (PMLD). Hum. Genet. 2019, 138, 1409-1417. [CrossRef]

203. Poojary, S.; Shah, K.S.; Bhalala, K.B.; Hegde, A.U. CEDNIK syndrome in an Indian patient with a novel mutation of the SNAP29 gene. Pediatr. Dermatol. 2019, 36, 372-376. [CrossRef] [PubMed]

204. McDonald-McGinn, D.M.; Fahiminiya, S.; Revil, T.; Nowakowska, B.A.; Suhl, J.; Bailey, A.; Mlynarski, E.; Lynch, D.R.; Yan, A.C.; Bilaniuk, L.T.; et al. Hemizygous mutations in SNAP29 unmask autosomal recessive conditions and contribute to atypical findings in patients with 22q11.2DS. J. Med. Genet. 2013, 50, 80-90. [CrossRef]

205. Zhang, J.; Fu, Y.; Zhao, Y.; Li, F.; Qian, A.; Wu, B.; Li-Ling, J. Genetic analysis of genitourinary malformations. Zhonghua Yi Xue Yi Chuan Xue Za Zhi 2009, 26, 134-138. [CrossRef]

206. Sprecher, E.; Ishida-Yamamoto, A.; Mizrahi-Koren, M.; Rapaport, D.; Goldsher, D.; Indelman, M.; Topaz, O.; Chefetz, I.; Keren, H.; O'Brien, T.J.; et al. A Mutation in SNAP29, Coding for a SNARE Protein Involved in Intracellular Trafficking, Causes a Novel Neurocutaneous Syndrome Characterized by Cerebral Dysgenesis, Neuropathy, Ichthyosis, and Palmoplantar Keratoderma. Am. J. of Hum. Genet. 2005, 77, 242-251. [CrossRef] [PubMed]

207. Fuchs-Telem, D.; Stewart, H.; Rapaport, D.; Nousbeck, J.; Gat, A.; Gini, M.; Lugassy, Y.; Emmert, S.; Eckl, K.; Hennies, H.C.; et al. CEDNIK syndrome results from loss-of-function mutations in SNAP29. Br. J. Dermatol. 2011, 164, 610-616. [CrossRef] [PubMed]

208. Praschberger, R.; Lowe, S.A.; Malintan, N.T.; Giachello, C.N.G.; Patel, N.; Houlden, H.; Kullmann, D.M.; Baines, R.A.; Usowicz, M.M.; Krishnakumar, S.S.; et al. Mutations in Membrin/GOSR2 Reveal Stringent Secretory Pathway Demands of Dendritic Growth and Synaptic Integrity. Cell Rep. 2017, 21, 97-109. [CrossRef]

209. Praschberger, R.; Balint, B.; Mencacci, N.E.; Hersheson, J.; Rubio-Agusti, I.; Kullmann, D.M.; Bettencourt, C.; Bhatia, K.; Houlden, H. Expanding the Phenotype and Genetic Defects Associated with the GOSR2 Gene. Mov. Dis. Clin. Pract. 2015, 2, 271-273. [CrossRef]

210. Corbett, M.A.; Schwake, M.; Bahlo, M.; Dibbens, L.M.; Lin, M.; Gandolfo, L.C.; Vears, D.F.; O'Sullivan, J.D.; Robertson, T.; Bayly, M.A.; et al. A Mutation in the Golgi Qb-SNARE Gene GOSR2 Causes Progressive Myoclonus Epilepsy with Early Ataxia. Am. J. Hum. Genet. 2011, 88, 657-663. [CrossRef]

211. Bräuer, P.; Parker, J.L.; Gerondopoulos, A.; Zimmermann, I.; Seeger, M.A.; Barr, F.A.; Newstead, S. Structural basis for $\mathrm{pH}$-dependent retrieval of ER proteins from the Golgi by the KDEL receptor. Science 2019, 363, 1103-1107. [CrossRef] 
212. Bhide, G.P.; Colley, K.J. Sialylation of N-glycans: Mechanism, cellular compartmentalization and function. Histochem. Cell Biol. 2017, 147, 149-174. [CrossRef] [PubMed]

213. Nilsson, T.; Hoe, M.H.; Slusarewicz, P.; Rabouille, C.; Watson, R.; Hunte, F.; Watzele, G.; Berger, E.G.; Warren, G. Kin recognition between medial Golgi enzymes in HeLa cells. EMBO J. 1994, 13, 562-574. [CrossRef] [PubMed]

214. Nilsson, T.; Rabouille, C.; Hui, N.; Watson, R.; Warren, G. The role of the membrane-spanning domain and stalk region of $\mathrm{N}$-acetylglucosaminyltransferase I in retention, kin recognition and structural maintenance of the Golgi apparatus in HeLa cells. J. Cell. Sci. 1996, 109, 1975-1989.

215. Nilsson, T.; Slusarewicz, P.; Hoe, M.H.; Warren, G. Kin recognition. A model for the retention of Golgi enzymes. FEBS Lett. 1993, 330, 1-4. [CrossRef]

216. Chen, C.; Ma, J.; Lazic, A.; Backovic, M.; Colley, K.J. Formation of Insoluble Oligomers Correlates with ST6Gal I Stable Localization in the Golgi. J. Biol. Chem. 2000, 275, 13819-13826. [CrossRef] [PubMed]

217. Fenteany, F.H.; Colley, K.J. Multiple Signals Are Required for $\alpha 2,6$-Sialyltransferase (ST6Gal I) Oligomerization and Golgi Localization. J. Biol. Chem. 2005, 280, 5423-5429. [CrossRef]

218. Opat, A.S.; Houghton, F.; Gleeson, P.A. Medial Golgi but Not Late Golgi Glycosyltransferases Exist as High Molecular Weight Complexes Role of Luminal Domain in Complex Formation and Localization. J. Biol. Chem. 2000, 275, 11836-11845. [CrossRef]

219. Hassinen, A.; Kellokumpu, S. Organizational Interplay of Golgi N-Glycosyltransferases Involves Organelle Microenvironment-Dependent Transitions between Enzyme Homo- and Heteromers. J. Biol. Chem. 2014, 289, 26937-26948. [CrossRef]

220. Kellokumpu, S. Golgi pH, Ion and Redox Homeostasis: How Much Do They Really Matter? Front. Cell Dev. Biol. 2019, 7. [CrossRef]

221. Kokkonen, N.; Rivinoja, A.; Kauppila, A.; Suokas, M.; Kellokumpu, I.; Kellokumpu, S. Defective acidification of intracellular organelles results in aberrant secretion of cathepsin D in cancer cells. J. Biol. Chem. 2004, 279, 39982-39988. [CrossRef]

222. Ghosh, P.; Dahms, N.M.; Kornfeld, S. Mannose 6-phosphate receptors: New twists in the tale. Nat. Rev. Mol. Cell Biol. 2003, 4, 202-212. [CrossRef]

223. Caplan, M.J.; Stow, J.L.; Newman, A.P.; Madri, J.; Anderson, H.C.; Farquhar, M.G.; Palade, G.E.; Jamieson, J.D. Dependence on $\mathrm{pH}$ of polarized sorting of secreted proteins. Nature 1987, 329, 632-635. [CrossRef]

224. Guo, Y.; Sirkis, D.W.; Schekman, R. Protein sorting at the trans-Golgi network. Annu. Rev. Cell Dev. Biol. 2014, 30, 169-206. [CrossRef] [PubMed]

225. Morava, E.; Wopereis, S.; Coucke, P.; Gillessen-Kaesbach, G.; Voit, T.; Smeitink, J.; Wevers, R.; Grünewald, S. Defective protein glycosylation in patients with cutis laxa syndrome. Eur. J. Hum. Genet. 2005, 13, 414-421. [CrossRef] [PubMed]

226. Rajab, A.; Kornak, U.; Budde, B.S.; Hoffmann, K.; Jaeken, J.; Nürnberg, P.; Mundlos, S. Geroderma osteodysplasticum hereditaria and wrinkly skin syndrome in 22 patients from Oman. Am. J. Med. Genet. Part A 2008, 146A, 965-976. [CrossRef] [PubMed]

227. Marklová, E.; Albahri, Z. Screening and diagnosis of congenital disorders of glycosylation. Clin. Chim. Acta 2007, 385, 6-20. [CrossRef]

(C) 2020 by the authors. Licensee MDPI, Basel, Switzerland. This article is an open access article distributed under the terms and conditions of the Creative Commons Attribution (CC BY) license (http://creativecommons.org/licenses/by/4.0/). 